\title{
Revisiting nature: a review of iridoids as a potential antileishmanial class
}

\author{
Guilherme Arraché Gonçalves (i) - Vera Lucia Eifler-Lima • \\ Gilsane Lino von Poser
}

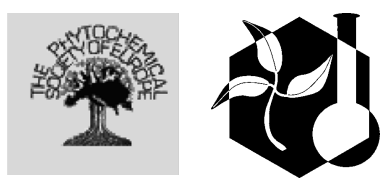

Received: 9 September 2020/ Accepted: 2 March 2021 / Published online: 16 March 2021

(C) The Author(s), under exclusive licence to Springer Nature B.V. 2021

\begin{abstract}
Leishmaniasis still stands as one of the most prevalent neglected tropical diseases in the least developed and emerging countries. The recommended therapeutic arsenal to treat leishmaniasis is characterized by several shortcomings, and resistance has already been reported. Hence, this dramatic background highlights the pressing need to develop novel, affordable, and safe antileishmanial drugs. Multiple classes of natural compounds have been reported to possess antileishmanial activity. Among these classes, iridoids stand out as a special type of monoterpenoids with diverse biological properties-including their antileishmanial potential. This review aims to discuss the available literature between 1991 and 2020 related to the antileishmanial activity of the iridoid class. Throughout the past decades, various investigations attributed antileishmanial action to assorted iridoid types, including inhibitory potential towards validated drug targets and immunomodulatory activity. The latter deserves special attention due to the ability of
\end{abstract}

G. Arraché Gonçalves $(\bowtie)$ · V. L. Eifler-Lima Laboratório de Síntese Orgânica Medicinal (LaSOM), Programa de Pós-Graduação em Ciências Farmacêuticas, Faculdade de Farmácia, Universidade Federal do Rio Grande do Sul, Porto Alegre, RS 90610-000, Brazil e-mail: arracheg@gmail.com some iridoids to improve the host's immune response against parasites. It opens the possibility of iridoids become adjuncts in leishmaniasis treatments by improving the efficacy of currently employed drugs. Furthermore, the present study intends to provide a convenient visual representation of which iridoids and Leishmania spp. species have been most investigated as a guide for further researches.

Keywords Iridoids $\cdot$ Leishmaniasis $\cdot$ Neglected tropical diseases $\cdot$ Antileishmanial $\cdot$ Natural products
Abbreviations
NTD(s) Neglected tropical disease(s)
CL Cutaneous leishmaniasis
MCL Mucocutaneous leishmaniasis
VL Visceral leishmaniasis
Glc Glucose
SI Selectivity index
TyR Trypanothione reductase
$\mathrm{K}_{\mathrm{i}} \quad$ Inhibitory constant
$\mathrm{IC}_{50} \quad$ Half inhibitory concentration
$\mathrm{CC}_{50} \quad$ Half cytotoxic concentration
$\mathrm{EC}_{50} \quad$ Half effective concentration
ROS Reactive oxygen species
MIC Minimum inhibitory concentration

G. L. von Poser

Laboratório de Farmacognosia, Programa de Pós-

Graduação em Ciências Farmacêuticas, Faculdade de Farmácia, Universidade Federal do Rio Grande do Sul, Porto Alegre, RS 90610-000, Brazil 


\section{Introduction}

General aspects of leishmaniasis

Neglected tropical diseases (NTDs) comprise a group of diseases related to poor living conditions, mostly prevailing in tropical and subtropical regions. In this context, leishmaniasis persists as one of the most prevalent NTDs in the least developed and emerging countries. The socioeconomic impacts combined with the complexity of the disease still challenges endemic countries as a public health problem (Malecela 2019; Sunyoto et al. 2019). Although much effort is still needed in terms of prevention, control, and novel treatments, recent progress has been made (Bodimeade et al. 2019). Control strategies implemented in Bihar, India, successfully eliminated visceral leishmaniasis in a highly-endemic district (Kumar et al. 2020); however, there is a concern where the emergence of Coronavirus disease 2019 (COVID-19) may reverse decades of efforts and aggravate the NTDs scenario in vulnerable populations (Ehrenberg et al. 2020).

The highly diverse genus Leishmania consists of multiple species of obligate intracellular parasites, mainly transmitted by female sandflies of the genera Lutzomiya and Phlebotomus. Each species is responsible for a particular sort of clinical manifestation, which may be categorized as: cutaneous leishmaniasis (CL), mucocutaneous leishmaniasis (MCL), and visceral leishmaniasis (VL). In fact, some species cause more than one clinical manifestation; for instance, $L$. amazonensis infections are commonly associated with CL, as well as with diffuse CL (Kaye and Scott 2011; Torres-Guerrero et al. 2017). The damages caused by leishmaniasis go beyond physical injuries. From lifelong skin scarring to facial mucosal deformities, CL and MCL, respectively, may lead to aesthetic and social stigma. As a result, this psychosocial burden affects directly the psychological health and quality of life of those affected (Bennis et al. 2018; Bailey et al. 2019). Known as kala-azar, VL is the most severe condition of this group of diseases, affecting internal organs such as the spleen, liver, and bone marrow. This systemic form of the disease features ineffective immune response in the host and high mortality, comparing to other leishmaniasis clinical manifestations (Kaye and Scott 2011; Torres-Guerrero et al. 2017). Consequently, at-risk populations such as preschool children, undernourished, and immunocompromised individuals require special attention (TorresGuerrero et al. 2017).

Leishmania spp. life cycle

The life cycle of Leishmania spp. parasites (Fig. 1) comprehend a complex relationship between a female sandfly vector and a vertebrate host (e.g., humans and rodents). This human-vector interaction is related to various circumstances, which anthropic interventions such as deforestation and exposure to wildlife certainly contributed to human infections. In urban areas, dogs are the main reservoirs of Leishmania species responsible for VL, thus participating in the infection cycle and contributing to the disease spread (TorresGuerrero et al. 2017; Roque and Jansen 2014). Leishmania parasites occur as flagellated promastigotes and intracellular amastigotes. The flagellated forms are found in sandfly vectors and subdivided as procyclic (non-infective) and metacyclic (infective) promastigotes. The parasites adopt an oval form known as amastigotes to overcome the intracellular environment in the vertebrate host (Rossi and Fasel 2017). Immune evasion and modulation are essential strategies for parasite survival. The constant exposure to harsh environments during its digenetic cycle induces morphological and biochemical changes in the parasite (Dostálová and Volf 2012). To properly establish in the host, the parasite must evade and modulate the host's immune system through multiple mechanisms. As expected, an immunocompromised host facilitates the persistence of the parasite. This is a typical scenario in Leishmania-HIV co-infected patients. Indeed, disease relapses and worsening of $\mathrm{CL}$ and VL clinical symptoms are quite common in patients affected with this serious condition (Kaye and Scott 2011; Conceição-Silva and Morgado 2019; Rossi and Fasel 2017; Geiger et al. 2016).

In general, the digenetic life cycle of Leishmania spp. parasites (Fig. 1) may be divided into vector and vertebrate host phases. In the vector phase, the flagellated procyclic promastigote forms are localized in the midgut of the sandfly. These non-infective spindle shaped parasites differentiate into infectious metacyclic promastigotes, and then are inoculated into the skin of the vertebrate host during sandfly blood feeding. Various types of phagocytic cells are recruited to the site of the bite (Kaye and Scott 


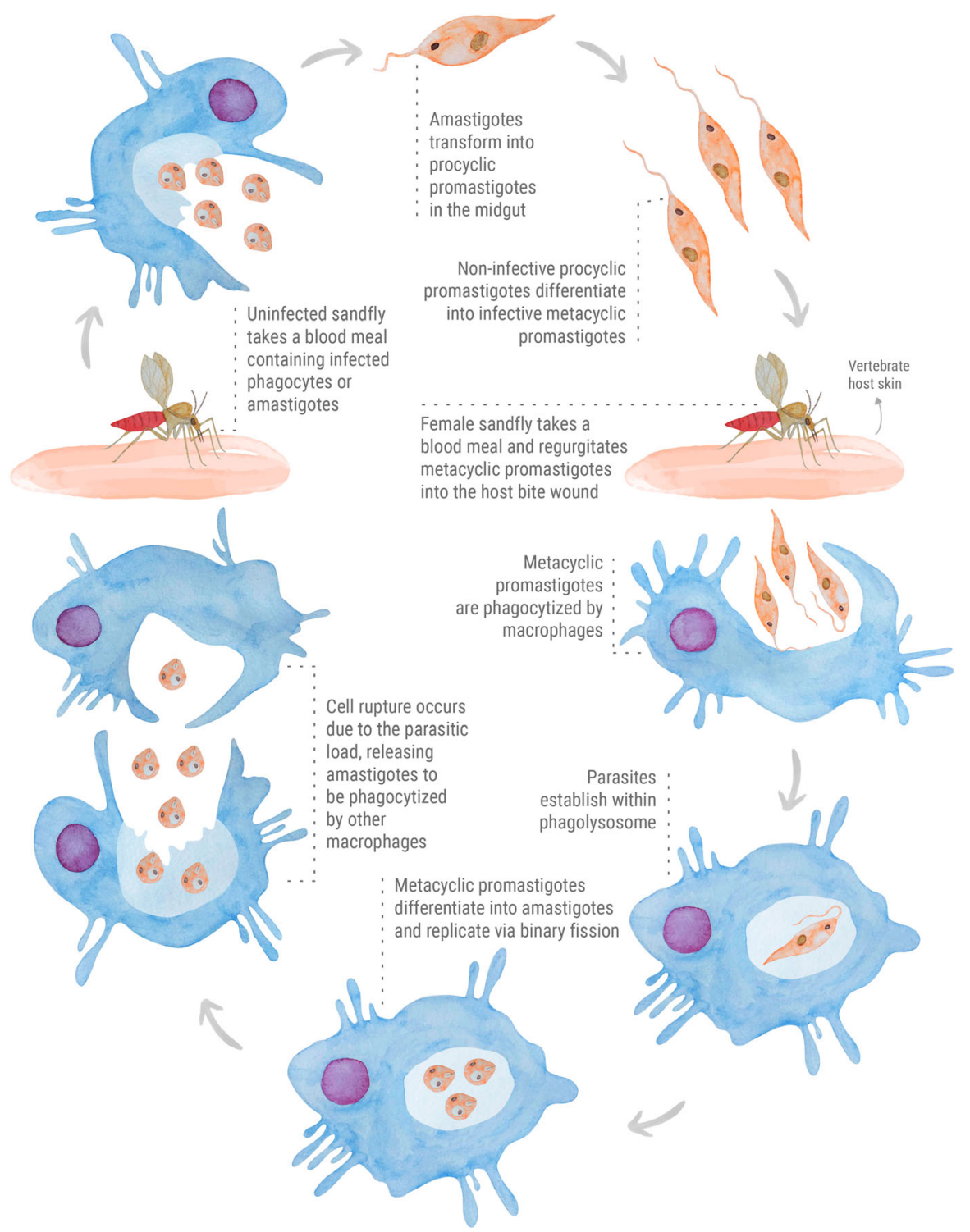

Fig. 1 The digenetic life cycle of Leishmania spp. parasites

2011; Séguin et al. 2016). Before being phagocytized, the parasites surpass the extracellular matrix with the assistance of secreted proteases to breakdown collagen, thus facilitating their migration (de Menezes et al. 2016). Generally, Leishmania-macrophage initial interactions occur through parasite flagellum. Once phagocytized by macrophages, the metacyclic promastigotes establish within phagolysosome and differentiate into amastigotes. In this host phase, the intracellular parasites replicate via binary fission and persist by secreting survival factors to counter the oxidative damage and hydrolytic activity of phagolysosome. These oval forms replicate until the organelle become unable to support the parasitic load, causing cell rupture. Later on, the amastigotes are released and internalized by other phagocytic cells, gradually establishing the infection in the host (Podinovskaia and Descoteaux 2015; Moradin and Descoteaux 2012). The life cycle is complete when an uninfected sandfly takes a blood meal containing infected phagocytes or amastigotes (Kaye and Scott 2011; Dostálová and Volf 2012). 
Current treatments on leishmaniasis

Recommended treatment regimens still rely on few drug options (Fig. 2), which present several drawbacks and limited efficacy, depending on the clinical manifestation. Multiple factors are involved in the correct chemotherapy choice, which may vary according to regional or national guidelines (Graebin et al. 2009; Sundar et al. 2019). In addition to important adverse effects, drug resistance has already been reported for currently employed drugs (Sundar et al. 2019; Tiwari et al. 2018). Current strategies to overcome the lack of treatment options are based on drug repurposing, multidrug therapy, and development of novel compounds. Another interesting approach is the development of new formulations for currently employed drugs, such as novel drug delivery systems (Sundar et al. 2019; Charlton et al. 2018; Sundar and Singh 2016).

Sodium stibogluconate (1) and $N$-methylglucamine antimoniate (2) (Fig. 2) are antimonial-based drugs normally available in endemic areas and present low cost. Pentavalent antimonials $\mathbf{1}$ and $\mathbf{2}$ are the first choice in many endemic countries for CL and VL. The wide range of adverse effects of these compounds includes vomiting, cardiotoxicity, and hepatotoxicity (Graebin et al. 2009; Sundar and Singh 2016). Pentamidine (3) belongs to the diamidine class and may be employed as second-choice treatment when antimonial therapy is unsuccessful. Its use is associated with the development of insulin-dependent diabetes mellitus in patients, as well as hypoglycemia, renal toxicity, and myocarditis (Sundar and Singh 2016; Chakravarty and Sundar 2019). The first oral drug for leishmaniasis, miltefosine (4), is effective in the CL and VL treatment. One of the major concerns regarding 4 is the emergence of resistance owing to its long half-life. The most severe side effects related to its use are gastrointestinal toxicity, hepatotoxicity, and nephrotoxicity. Additionally, teratogenicity has been reported in rats, hence the use of $\mathbf{4}$ by pregnant women is not recommended (Sundar and Singh 2016; Chakravarty and Sundar 2019; Dorlo et al. 2012). The antibiotics used to treat leishmaniasis are
Fig. 2 Therapeutic options to treat leishmaniasis

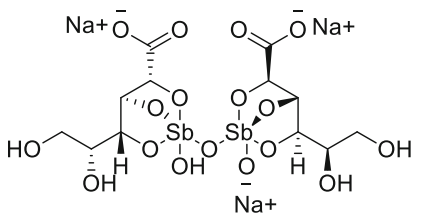

1 Sodium Stibogluconate<smiles>N=C(N)c1ccc(OCCCCCOc2ccc(C(=N)N)cc2)cc1</smiles><smiles>CCCCCCCCCCCCCCCOP(=O)([O-])OCC[N+](C)(C)C</smiles><smiles>NCC1OC(OC2[C@H](CO)O[C@@H](O[C@@H]3[C@@H](O)[C@H](N)C[C@H](N)[C@H]3O[C@H]3O[C@H](CO)[C@@H](O)[C@H](O)[C@H]3N)[C@H]2O)[C@H](N)[C@@H](O)[C@H]1O</smiles> 
represented by amphotericin B (5) and paromomycin sulfate (6). Amphotericin B 5 is generally used as a second-choice drug, being an alternative to treat antimonial-resistant cases. Chemotherapy with $\mathbf{5}$ is associated with its known nephrotoxicity and long unpleasant infusion administrations. The serious adverse effects caused by $\mathbf{5}$ require close monitoring and extended hospitalization. Liposomal formulations of $\mathbf{5}$ are highly effective due to their unique delivery system. These presentations circumvent the toxicity associated to $\mathbf{5}$, although much research is still needed to decrease their cost (Sundar and Singh 2016; Chakravarty and Sundar 2019; Ortega et al. 2017). Paromomycin sulfate 6, also known as aminosidine, is an aminoglycoside antibiotic alternatively used to treat leishmaniasis. Depending on the treatment guideline, $\mathbf{6}$ is used in combination with antimonials. Similar to 5, 6 parenteral administrations are painful and also may cause nephrotoxicity. In fewer cases, reversible ototoxicity occurs as a serious adverse effect (Sundar and Singh 2016; Chakravarty and Sundar 2019; Matos et al. 2020).

\section{Approaches to find new antileishmanial agents from plants}

The aspects discussed above highlight the main reasons why leishmaniasis has the NTD status. In this sense, there is a pressing need to develop novel, safe, and affordable drugs to treat leishmaniasis in its entire clinical manifestation spectrum. To accomplish that, a classic strategy is the investigation of plants and their constituents aiming to combat the disease in question (Ullah et al. 2016). Endeavors such as plant-screening programs have identified that several plants employed in folk medicine present antileishmanial activity (Rocha et al. 2005). The study of ethnomedical knowledge of communities and natives from certain regions is another approach where potential antileishmanial extracts and plant-derived compounds may be identified (Ullah et al. 2016; Rocha et al. 2005; Scotti et al. 2016).

The chemical diversity and complexity of natural compounds have always fascinated researchers regarding their pharmacological potential. Plant extracts and phytochemicals of various classes have been reported to possess antileishmanial properties (Scotti et al. 2016; Boniface and Ferreira 2019;
Gonçalves et al. 2020; Raj et al. 2020). Among these classes, iridoids comprise a vastly diverse group of cyclopenta[c]pyran monoterpenoids (Raj et al. 2020). Throughout the past decades, extensive investigations have been conducted and attributed various biological activities to this class, including antileishmanial properties (Raj et al. 2020; Tundis et al. 2008).

Taking into account these matters, the present study aims to discuss the available literature between 1991 and 2020 related to the antileishmanial activity of iridoids. In this period, a total of 32 works were published, comprising in vitro, in vivo, ex vivo, and in silico studies. The available information was gathered using different databases (Web of Science, ScienceDirect, and Scopus) using the words iridoids, antileishmanial, leishmanicidal, antiparasitic, and antiprotozoal. Additional data from books were also included. All 32 publications were covered in this review, regardless of the lack of antileishmanial activity. Considering the present work aims to discuss the available data, it is appropriate to report negative results to optimize further studies. Genus Leishmania has numerous species and different forms, which may present varying susceptibilities towards the same compound; therefore, different species and forms may be investigated, and redundant studies prevented. To the best of our knowledge, this is the first review article entirely dedicated to the antileishmanial potential of the iridoid class.

\section{Iridoids as a potential antileishmanial class}

A glimpse on iridoid chemistry

Iridoids are a special class of cyclopentanoid monoterpenes that occur in the plant kingdom as glycosides,

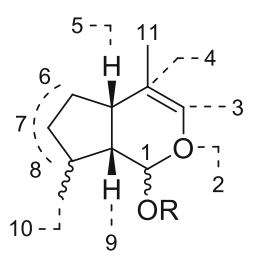

7 Carbocyclic iridoid

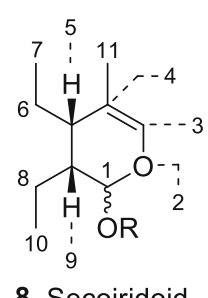

8 Secoiridoid
Fig. 3 Basic structure of iridoids. In general, iridoids are often found as glucosides, featuring a $\beta$-D-glucopyranosyl unit attached at $\mathrm{C}$-1 via a $\beta$-hemiacetalic bond $(\mathrm{R}=$ glucose $)$ 
regularly bound to glucose at $\mathrm{C}-1$. The basic skeleton of carbocyclic iridoids (Fig. 3) generally features a cyclopentane unit attached to a dihydropyran ring, whereas secoiridoids occur as a result of the C-7/C-8 cleavage. These compounds are considered chemotaxonomic markers and their occurrence have been providing evidences that allow the circumscription of many taxa whose taxonomic boundaries are confusing and unresolved (Jensen and Shripsema 2002; Franzyk 2000).

Iridoids are formed by two principal biosynthetic routes (Fig. 4). Route I originates compounds that are mainly found in species of the orders Cornales and Gentianales. This pathway leads to the synthesis of deoxyloganic acid (11), which is a precursor to many iridoids with the $8 \beta$ stereochemistry, including loganin (12), and secologanin (13). The latter results from the oxidative cleavage of the C-7/C-8 linkage of the cyclopentane ring. After a complex synthesis involving tryptamine, $\mathbf{1 3}$ gives rise to indole alkaloids; vincristine, vinblastine, and reserpine, among others, are usually found in the families Apocynaceae, Rubiaceae, and Loganiaceae, order Gentianales. Other group of iridoids, which may be considered more advanced, is biosynthetically formed through route II. This pathway gives rise to 8-epi-deoxyloganic acid (14), which is a precursor to iridoids with 8- $\alpha$ carbon substituent, both C-4 carboxylated and C-4 decarboxylated carbocyclic iridoids (e.g., ipolamiide (15) and aucubin (16), respectively). These compounds are almost exclusively found in families of the order Lamiales (Jensen 1992).

A large number of iridoids isolated from plants employed in traditional medicine have shown biological activities, thus validating their popular use all over the world. This class of monoterpenoids exhibits a wide range of biological effects, such as antiviral, antidiabetic, anticancer, anti-inflammatory, hepatoprotective, neuroprotective, molluscicidal, among many others (Bhattamisra et al. 2019; Zeng et al. 2020; Wang et al. 2020; Hamdi and Castellon 2005; de Sa Barreto et al. 2007; Kubo and Matsumoto 1984; Drewes et al. 1996). Furthermore, some iridoids have shown antiprotozoal activity against Plasmodium spp. (Tamura et al. 2010; Rocha e Silva et al. 2013), Trypanosoma spp. (Kwofie et al. 2016), and Leishmania spp., the focus of this review. Indeed, the antiLeishmania activity of iridoids has been drawing the attention of the scientific community for several decades (Hussain et al. 2014, 2019). The following section is dedicated to the discussion of several investigations that explored the antileishmanial potential of the iridoid class.

Antileishmanial properties of iridoids

Around 22 plant species and their corresponding phytochemicals, specifically iridoids (52 substances), were analyzed in this review. With some exceptions, the majority of plants herein discussed belong to the orders Gentianales and Lamiales. In brief, the in vitro antileishmanial evaluations were performed using the promastigote and amastigote forms of Leishmania spp. parasites. Eight Leishmania species have been investigated so far: L. donovani, L. major, L. hertigi, $L$. enriettii, L. amazonensis, L. braziliensis, L. infantum, and L. mexicana (in order of appearance). It is important to keep in mind that the intracellular forms, amastigotes, play a key role in the emergence of leishmaniasis clinical manifestations; therefore, these forms deserve an extra attention. Some studies are dedicated to the in vivo assessment of iridoids in experimental VL models. Organ biopsies were the main objects to evaluate the parasite load after treatment termination.

The investigation of Nyctanthes arbor-tristis L. (Oleaceae) biological potential led to the discovery of its antileishmanial properties. The $n$ - $\mathrm{BuOH}$ fraction extracted from its seeds, which exhibited antileishmanial activity in a previous screening, resulted in the subsequent isolation of the iridoid glucosides arbortristoside A (17), arbortristoside B (18), arbortristoside C (19), and 6 $\beta$-hydroxyloganin (20) (Fig. 5). These isolates were evaluated both in vivo and in vitro against the amastigote forms of $L$. donovani. The compounds were assessed using two concentrations. All compounds presented some degree of activity in both concentrations tested, where $\mathbf{1 7}$ displayed a percentage of inhibition of average number of amastigotes per infected macrophage of $45.83 \pm 7.21 \%$ at $30 \mu \mathrm{g} / \mathrm{mL} \quad(52.95 \mu \mathrm{M})$ and $64.58 \pm 3.60 \%$ at $100 \mu \mathrm{g} / \mathrm{mL}(176.55 \mu \mathrm{M})$. Unfortunately, 19 and 20 were toxic against macrophages at $60 \mu \mathrm{g} / \mathrm{mL}$ (108.59 $\mu \mathrm{M}$ and $147.64 \mu \mathrm{M}$, respectively). In the same test conditions, the standard drug sodium stibogluconate (1) showed a percentage of inhibition of average number of amastigotes per infected macrophage of $80 \%$ and $100 \%$ at $30 \mu \mathrm{g} / \mathrm{mL}$ 
Fig. 4 Iridoid biosynthesis from route I and II. Adapted from Jensen (1992)

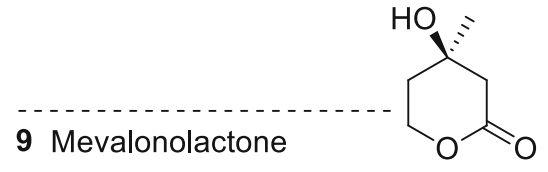<smiles>[3H]C</smiles>

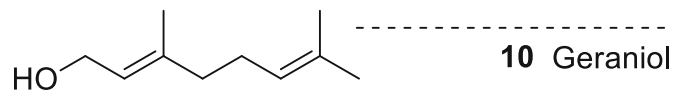

Route I

Route II

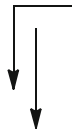<smiles>C[C@@H]1CCC2C(C(=O)O)=CO[C@H](OC(C)(O)Cl)[C@@H]21</smiles>

11

Deoxyloganic acid<smiles>COC(=O)C1=CO[C@@H](O)C2C1CC(O)[C@H]2O</smiles>

12 Loganin<smiles>C=C[C@H]1[C@@H](O[GeH3])OC=C(C(=O)OC)[C@@H]1CC=O</smiles>

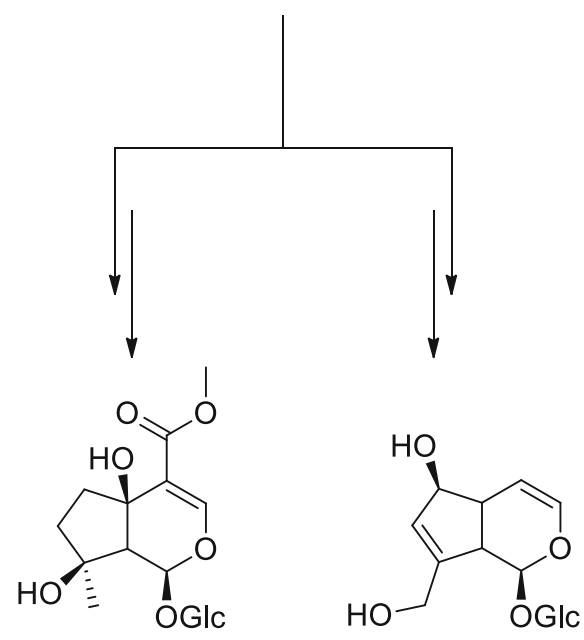

15 Ipolamiide<smiles>CO[C@H]1OC=C(C(=O)O)C2CC[C@@H](C)[C@H]21</smiles>

14 8-epi-deoxyloganic acid

16 Aucubin Complex indole alkaloids

13 Secologanin

$(32.93 \mu \mathrm{M})$ and $100 \mu \mathrm{g} / \mathrm{mL}(109.78 \mu \mathrm{M})$, respectively. The in vivo studies using hamsters infected with $L$. donovani yielded interesting results. Iridoid glucosides 17-20 were administered via intraperitoneal at a dose of $10 \mathrm{mg} / \mathrm{kg}$ given for 5 days. The parasite burden was evaluated after spleen biopsies 

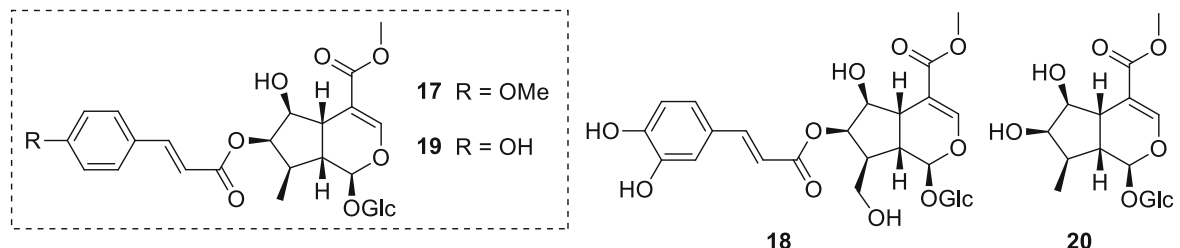

20

Fig. 5 Nyctanthes arbor-tristis iridoid glucosides: arbortristoside A (17), arbortristoside B (18), arbortristoside C (19), and 6- $\beta$ hydroxyloganin (20)

and expressed as percentage of inhibition. Spleen biopsies on days 7 and 28 post treatment revealed a significant antileishmanial activity for compound $\mathbf{1 7}$ (79.68 $\pm 21.68 \%$ of inhibition on day 28). Furthermore, 17 was also administered orally at $100 \mathrm{mg} / \mathrm{kg}$ given for 5 days and produced $57 \%$ of inhibition. In contrast, no inhibition was observed for $\mathbf{1 9}$, indicating that the para-methoxy substituent at the cinnamoyl portion is important for the activity. As positive control, 1 administered intraperitoneally at $100 \mathrm{mg} / \mathrm{kg}$ given for 5 days exhibited $93.51 \%$ of inhibition (day 28) (Tandon et al. 1991).

The findings of the previous work promoted a deepen analysis concerning compounds arbortristoside A (17), arbortristoside C (19), and 6 $\beta$-hydroxyloganin (20) mechanism of action (Fig. 5). Trypanothione reductase (TryR) is a unique enzyme present in Trypanosomatids responsible for the maintenance of redox balance and homeostasis. The absence of TryR in mammalian hosts is an enormous advantage in the drug development perspective, thus being considered a validated drug target. In this work, compounds 17, 19, and 20 were isolated from $N$. arbor-tristis seeds and their inhibitory potential was evaluated towards TryR. All iridoid glucosides displayed competitive inhibition of TryR, showing $\mathrm{K}_{\mathrm{i}}$ values of $3.34 \pm 0.03 \mu \mathrm{M}, 3.24 \pm 0.05 \mu \mathrm{M}$, and $6.49 \pm 0.05 \mu \mathrm{M}$ for isolates $\mathbf{1 7}, \mathbf{1 9}$, and $\mathbf{2 0}$, respectively. Moreover, the $\mathrm{IC}_{50}$ values demonstrated that all compounds were able to inhibit TryR at low concentrations. Whereas $\mathbf{1 7}$ and $\mathbf{1 9}$ exhibited similar inhibition values $(2.65 \pm 0.05 \mu \mathrm{M}$ and $2.29 \pm 0.03 \mu \mathrm{M}$, respectively), 20 showed an $\mathrm{IC}_{50}$ of $4.74 \pm 0.05 \mu \mathrm{M}$ against TryR (Shukla et al. 2011).

Continuing the investigation to better understand the antileishmanial activity of iridoid glucosides arbortristoside A (17), arbortristoside C (19), and 6 $\beta$-hydroxyloganin (20) (Fig. 5), various experiments were conducted. Promastigote forms of $L$. donovani were more susceptible to 17-19, in comparison to axenic amastigote forms. The most active isolate, $\mathbf{1 7}$, presented an $\mathrm{IC}_{50}$ value of $3.264 \pm 0.05 \mu \mathrm{M}$ and $7.26 \pm 0.05 \mu \mathrm{M}$ for promastigote forms and axenic amastigotes, respectively. It has been demonstrated that the iridoid glucosides $\mathbf{1 7}, \mathbf{1 9}$, and $\mathbf{2 0}$ promoted the increase of reactive oxygen species (ROS) in parasites. As a result, this redox imbalance induced oxidative stress, causing cell membrane damage and apoptosislike death in both promastigote and axenic amastigote forms. In addition, the toxicological assessment of the isolates indicated that these compounds may possess a safe profile, since low cytotoxicity was observed in human embryonic kidney (HEK 293) and mouse macrophage (J774A.1) cell lines. Low cytotoxicity towards macrophages represents a valuable finding since parasites reside inside them to replicate and persist (Shukla et al. 2012). Putting together all these data, it is evident that $N$. arbor-tristis is a valuable source of antileishmanial agents (Fig. 5). Its constituents 17-20, as well as its extracts, possess significant leishmanicidal activity against $L$. donovani. The increased ROS production in parasites, which leads to their apoptosis-like death, correlates well with the reported TryR inhibitory ability of iridoid glucosides $\mathbf{1 7}$ and $\mathbf{1 9}$.

The secoiridoid glucoside oleuropein (21) (Fig. 6) has been attracting substantial attention owing to its wide range of biological activities. Olive leaf extracts, which normally contains $\mathbf{2 1}$, are generally considered safe (Hamdi and Castellon 2005; Hassen et al. 2015). Isolated from Olea europaea L. (Oleaceae) leaves, 21 had its antileishmanial potential evaluated in vitro and in vivo. The leishmanicidal potential of $\mathbf{2 1}$ was investigated in three Leishmania species in vitro: $L$. infantum, L. donovani, and L. major. A preliminary screening showed that $L$. donovani promastigote forms were more susceptible to $\mathbf{2 1} \quad\left(\mathrm{IC}_{50}\right.$ $=77.2 \pm 10.5 \mu \mathrm{g} / \mathrm{mL}, 142.82 \pm 19 \mu \mathrm{M})$. Following 
<smiles>C/C=C1\[C@H](OC)OC=C(C(=O)OC)[C@@H]1CC(=O)OCCc1ccc(O)c(O)c1</smiles>

21

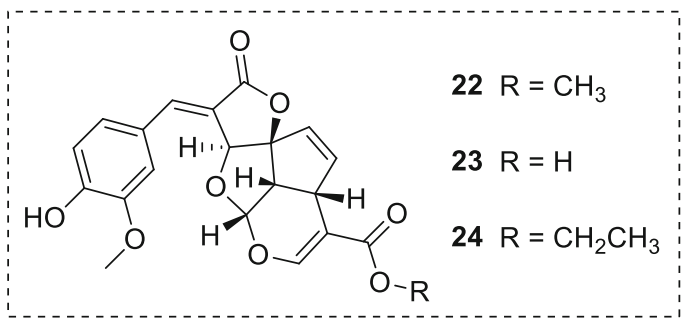

Fig. 6 Oleuropein (21), a secoiridoid glucoside isolated from O. europaea; tetracyclic iridoids (22-24) from M. lucida

these results, 21 was screened against $L$. donovani amastigote forms and exhibited an $\mathrm{IC}_{50}$ value of $110 \pm 32 \mu \mathrm{g} / \mathrm{mL}(203.51 \pm 59 \mu \mathrm{M})$. Both reference drugs miltefosine (4) and paromomycin (6) were highly active against promastigote and amastigote forms of all parasites. However, 21 exhibited less cytotoxicity against mouse macrophage (J774A.1) cell lines $\left(\mathrm{CC}_{50}=356 \pm 23 \mu \mathrm{g} / \mathrm{mL}, \quad 658.86 \pm 42 \mu \mathrm{M}\right)$ than $4 \quad\left(\mathrm{CC}_{50}=143 \pm 43 \mu \mathrm{g} / \mathrm{mL}\right.$, $350.83 \pm 105 \mu \mathrm{M})$ and $\mathbf{6}\left(\mathrm{CC}_{50}=275 \pm 53 \mu \mathrm{g} / \mathrm{mL}\right.$, $385.31 \pm 74 \mu \mathrm{M})$. Miltefosine 4 presented a selectivity index (SI) of 297.9, while $\mathbf{2 1}$ was less selective towards amastigotes $(\mathrm{SI}=3.24)$. Albeit 21 did not present an expressive in vitro activity against the parasites, the in vivo studies demonstrated the opposite. Oleuropein $\mathbf{2 1}$ was able to reduce significantly the parasitic burden in BALB/c mice infected with $L$. donovani. In this experimental VL model, 21 was administered intraperitoneally for 28 days using three concentrations $(45 \mathrm{mg} / \mathrm{kg}, 15 \mathrm{mg} / \mathrm{kg}$, and $5 \mathrm{mg} / \mathrm{kg}$ of body weight). Three days after treatment termination, it was observed that $\mathbf{2 1}$ significantly decreased the parasitic burden in BALB/c mice spleen and liver. To verify whether $\mathbf{2 1}$ was able to control the infection or relapse occurred, mice were sacrificed 6 weeks after treatment completion and their parasitic burden in the liver and spleen was evaluated. Oleuropein 21 exhibited a persistent leishmanicidal action and remarkably decreased the spleen parasitic burden at $45 \mathrm{mg} / \mathrm{kg}$ $(99.7 \%)$ and $15 \mathrm{mg} / \mathrm{kg}(99.8 \%)$, successfully inhibiting the progression of the disease. Miltefosine 4, which was used as positive control, showed similar results in the same conditions. It is appropriate to highlight $\mathbf{2 1}$ displayed lower in vitro cytotoxicity towards macrophages than $\mathbf{4}$, indicating a safer profile for 21 (Kyriazis et al. 2013). The study of an association between $\mathbf{4}$ and $\mathbf{2 1}$ would be an interesting approach for further researches.
The same research group investigated the possible mechanisms underlying oleuropein (21) (Fig. 6) antileishmanial action. This study not only demonstrated the ability of $\mathbf{2 1}$ to elevate ROS levels in both in vitro and in vivo VL models but also its capacity to increase nitric oxide production in ex vivo cultures of splenocytes and hepatocytes obtained from $L$. donovani-infected $\mathrm{BALB} / \mathrm{c}$ mice. Interestingly, $\mathbf{2 1}$ also presented a protective action in in vivo conditions by elevating Leishmania-specific IgG2a/IgG1 levels, as well as a positive delayed type hypersensitivity response. An immunomodulatory effect was also attributed to $\mathbf{2 1}$ due to its capacity to simultaneously downregulate antioxidant enzymes in parasites and to enhance host's immune response by increasing Th1 predominance (Kyriazis et al. 2016). In another study, L. donovani promastigote forms showed morphological changes and DNA fragmentation after treatment with 21 (under in vitro conditions). The experiments indicated that 21 promotes apoptosis-like death in parasites and intracellular ROS production after $48 \mathrm{~h}$ treatment. According to the authors, 21 may trigger apoptosis-like death through a ROS-independent mechanism (Kyriazis et al. 2017).

Oleuropein (21) (Fig. 6) has also displayed cytotoxic and antiproliferative activity against $L$. major promastigote forms. The secoiridoid glucoside $\mathbf{2 1}$ exhibited a dose-dependent activity against the flagellated forms of L. major. At a dose of $250 \mu \mathrm{g} / \mathrm{mL}$ $(462.52 \mu \mathrm{M}), 21$ reduced $88.5 \%$ of L. major promastigote forms, while $74.8 \%$ of parasites were killed when exposed to sodium stibogluconate (1) at $250 \mu \mathrm{g} /$ $\mathrm{mL}(274.45 \mu \mathrm{M})$. This cytotoxic action was investigated and it has been observed that $\mathbf{2 1}$ possesses apoptotic properties, triggering cell death through apoptosis in L. major promastigotes (Elamin and ALMaliki 2014). 
Previous reports have already pointed the antiprotozoal potential of tetracyclic iridoids, more specifically against Trypanosoma brucei parasites (Kwofie et al. 2016; Suzuki et al. 2015). The phytochemical investigation of Morinda lucida Benth. (Rubiaceae) leaves yielded the isolation of three tetracyclic iridoids (22-24) (Fig. 6). Considering Leishmania spp. and Trypanosoma spp. parasites are trypanosomatids and share common characteristics, the antileishmanial activity of the isolates 22-24 was assessed. Both $\mathbf{2 2}$ and $\mathbf{2 4}$ exhibited leishmanicidal action against $L$. hertigi and $L$. enriettii promastigote forms. While 22 displayed an $\mathrm{IC}_{50}$ of $4.24 \mu \mathrm{M}$ against $L$. hertigi and a minimum inhibitory concentration (MIC) of $4.17 \mu \mathrm{M}$ towards $L$. enriettii parasites, $\mathbf{2 4}$ presented a more pronounced activity. The tetracyclic iridoid $\mathbf{2 4}$ exhibited a half-inhibitory concentration of $3.38 \mu \mathrm{M}$ against L. hertigi and a MIC of $2.60 \mu \mathrm{M}$ against $L$. enriettii promastigotes. It is possible to infer that the presence of a carboxylate ester group is important for the activity, since the isolate $\mathbf{2 3}$ bearing a carboxylic acid did not show leishmanicidal action (L. hertigi: $\mathrm{IC}_{50-}$ $=>50 \mu \mathrm{M} ; \quad$ L. enriettii: $\mathrm{MIC}=>50 \mu \mathrm{M})$. Lipophilicity also seems important for the activity, by comparing the leishmanicidal action with the carboxylate ester side chain size. Concerning isolates 22 and 24 toxicity, both compounds exhibited cytotoxicity against different human cell lines in the range of 3.38-18.13 $\mu \mathrm{M}$. The presence of an $\alpha$-methylene $\gamma-$ lactone portion may play a role in the indiscriminate activity observed in the tetracyclic iridoids $\mathbf{2 2}$ and $\mathbf{2 4}$. Their increased lipophilicity, compared to $\mathbf{2 3}$, seems to enhance cell penetration; as a result, $\mathbf{2 2}$ and $\mathbf{2 4}$ may act as Michael-acceptors to biological nucleophiles, which explains their possible cytotoxic action towards human cell lines (Amoa-Bosompem et al. 2016).

The tetracyclic iridoids 22 and $\mathbf{2 4}$ (Fig. 6) have also showed significant activity against $L$. donovani $(\mathbf{2 2}$, $\mathrm{IC}_{50}=2.94 \pm 0.60 \mu \mathrm{M} ; \quad \mathbf{2 4}, \quad \mathrm{IC}_{50-}$ $=0.91 \pm 0.50 \mu \mathrm{M})$ and $L$. major $\left(\mathbf{2 2}, \quad \mathrm{IC}_{50-}\right.$ $\left.=1.85 \pm 0.20 \mu \mathrm{M} ; \quad \mathbf{2 4}, \quad \mathrm{IC}_{50}=1.77 \pm 0.20 \mu \mathrm{M}\right)$ promastigote forms. Microscopic analysis showed important morphological changes on parasites such as flagellum loss and induced cell-rounding. Additionally, apoptotic properties were attributed to isolates 22 and 24. Likewise the previous study, these compounds were isolated from M. lucida leaves (Azerigyik et al. 2018).

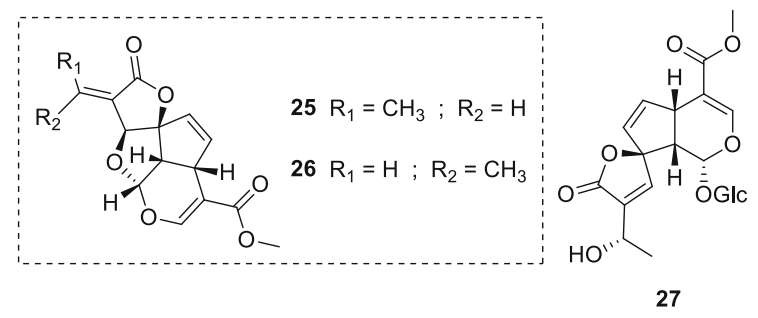

Fig. 7 Plumericin (25), isoplumericin (26), and plumieride (27)

Plumericin (25) and isoplumericin (26) (Fig. 7) are another well-known iridoids with reported antileishmanial properties. These highly functionalized iridoids were isolated from Plumeria rubra L. (syn. Plumeria bicolor Ruiz \& Pav.) (Apocynaceae) stem barks and assayed against $L$. donovani promastigote and amastigote forms. Plumericin 25 exhibited important antileishmanial activity against promastigote $\left(\mathrm{IC}_{50}=3.17 \pm 0.12 \mu \mathrm{M}\right)$ and amastigote ( $\mathrm{IC}_{50-}$ $=1.41 \pm 0.03 \mu \mathrm{M})$ forms. Curiously, the parasites were more resistant when treated with $\mathbf{2 6}\left(\mathrm{IC}_{50}\right.$ $=7.2 \pm 0.08 \mu \mathrm{M}$ for promastigotes; $\mathrm{IC}_{50}$ $=4.1 \pm 0.02 \mu \mathrm{M}$ for amastigotes). The chloroform extract, which yielded the isolates $\mathbf{2 5}$ and $\mathbf{2 6}$, displayed an $\mathrm{IC}_{50}$ of $21 \pm 2.2 \mu \mathrm{g} / \mathrm{mL}$ against promastigotes and $14 \pm 1.6 \mu \mathrm{g} / \mathrm{mL}$ towards intracellular amastigote forms. Cytotoxicity assessment against murine macrophage (J774G8) cell lines revealed a $\mathrm{CC}_{50}$ value of $24 \pm 0.7 \mu \mathrm{M}, 20.6 \pm 0.5 \mu \mathrm{M}$, and $75 \pm 5.3 \mu \mathrm{M}$ for $\mathbf{2 5}, \mathbf{2 6}$, and the chloroform extract, respectively. Plumericin $\mathbf{2 5}$ provoked cytopathological and morphological changes in $L$. donovani promastigotes, a similar action promoted by tetracyclic iridoids 22 and $\mathbf{2 4}$. The high activity displayed by tetracyclic iridoids $\mathbf{2 5}$ and $\mathbf{2 6}$ may be related to their propensity to undergo a Michael-type addition with biological nucleophiles (Sharma et al. 2011). Indeed, the tetracyclic iridoids $\mathbf{2 2}$ and $\mathbf{2 4}$ possess similar structural patterns and also presented cytotoxicity against macrophage cell lines (Amoa-Bosompem et al. 2016). Both isolates 25 and $\mathbf{2 6}$ showed less cytotoxicity against murine macrophage (J774G8) cell lines, although further studies are needed to verify their safety profile (Sharma et al. 2011).

Ethnomedical studies based on plants used by Peruvian Amazon region locals highlighted the antileishmanial properties of Himatanthus sucuuba (Spruce ex Mull. Arg.) Woodson (Apocynaceae). In this particular case, patients affected with CL apply $H$. 
sucuuba fresh barks and latex at the lesion site. The ethanolic extract obtained from this plant exhibited an $\mathrm{IC}_{50}$ of $5 \mu \mathrm{g} / \mathrm{mL}$ against L. amazonensis amastigote forms. Further extract purifications yielded the tetracyclic iridoids plumericin (25) and isoplumericin (26) (Fig. 7). Axenic amastigotes were highly susceptible to both isolates $\left(\mathbf{2 5}, \quad \mathrm{IC}_{50}=0.21 \mu \mathrm{M} ; \mathbf{2 6}, \mathrm{IC}_{50-}\right.$ $=0.28 \mu \mathrm{M})$. This strong activity also resulted in significant cytotoxicity against BALB/3T3 and Vero cell lines. The antileishmanial activity of $\mathbf{2 5}$ was also investigated in macrophages infected with amastigotes, and revealed an $\mathrm{IC}_{50}$ value of $0.9 \mu \mathrm{M}$. This assessment was not carried out with 26, since macrophages were affected in all tested concentrations (Castillo et al. 2007).

Five Brazilian medicinal plants were evaluated against $L$. amazonensis and $L$. braziliensis promastigote forms. Extracts and fractions of all investigated plants exhibited interesting activity. Allamanda schottii Pohl (Apocynaceae) root extracts stood out as the most promising source of antileishmanial compounds, yielding plumericin (25) and plumieride (27) (dichloromethane fraction). Plumericin 25 displayed a half inhibitory concentration value of $0.3 \pm 0.07 \mu \mathrm{g} / \mathrm{mL}$ $(1.03 \pm 0.24 \mu \mathrm{M}) \quad$ and $\quad 0.04 \pm 0.007 \mu \mathrm{g} / \mathrm{mL}$ $(0.13 \pm 0.02 \mu \mathrm{M})$ against $L$. amazonensis and $L$. braziliensis, respectively. Leishmania amazonensis promastigotes were more resistant to $\mathbf{2 7}\left(\mathrm{IC}_{50}\right.$ $=>100 \mu \mathrm{g} / \mathrm{mL},>212.57 \mu \mathrm{M}$ ), while the required concentration to inhibit half of $L$. braziliensis parasites was $21.3 \pm 2.80 \mu \mathrm{g} / \mathrm{mL}(45.27 \pm 5.95 \mu \mathrm{M})$ (Filho et al. 2013).

The leishmanicidal action of Valeriana jatamansi Jones (syn. Valeriana wallichii DC.) (Valerianaceae) rhizome extracts (Ghosh et al. 2011) resulted in further investigations concerning its constituents and their possible contribution to the activity. The isolates (28-31) (Fig. 8) were assayed against L. major promastigotes and showed significant activity $\left(\mathrm{IC}_{50-}\right.$ $=0.8-2.3 \mu \mathrm{g} / \mathrm{mL}, 1.52-4.98 \mu \mathrm{M})$. However, high cytotoxicity towards macrophages (J774.1 murine cell line) was also observed. The antileishmanial activity of 28-31 may be related to their cytotoxicity action against macrophages. Additional studies concerning their mechanism of action are required to validate this hypothesis. Isolates 28-31 feature multiple ester substituents, differing from other iridoids reported in this review. This information may support further structure-activity relationship and toxicological studies. Also, the leishmanicidal action of $V$. jatamansi rhizome extracts may be associated with iridoids 28-31, considering they represent the lowest $\mathrm{IC}_{50}$ values among all phytochemicals analyzed (e.g., flavonoids, terpenoids, and cinnamic acid derivatives) (Glaser et al. 2015).

Swertia chirata Buch.-Ham. ex Wall. (Gentianaceae) has been known to possess diversified biological properties, including antileishmanial activity (Singha et al. 1992). The secoiridoid glucoside amarogentin (32) (Fig. 8) was isolated from S. chirata aerial parts and assayed against $L$. donovani DNA topoisomerase I enzyme. Amarogentin 32 demonstrated a potent inhibitory capacity by binding to the enzyme and preventing the binary complex formation between DNA and topoisomerase I. This enzyme is involved in critical processes in Leishmania parasites, playing a crucial role in replication, transcription, repair, and mitosis events (Ray et al. 1996).

Amarogentin (32) (Fig. 8) has also exhibited encouraging results in $L$. donovani-infected hamsters. The in vivo antileishmanial potential of $\mathbf{3 2}$ was assessed in its free, liposomal, and niosomal forms. Subcutaneous administration at a dose of $2.5 \mathrm{mg} / \mathrm{kg}$ every 3 days (for 30 days) revealed that the liposomal and niosomal delivery systems reduced spleen parasite burden more efficiently than the free form. In fact, the 32 niosomal formulation was able to decrease the parasite load by $90 \%$. Toxicological evaluations indicated a safer profile for liposomal and niosomal preparations than the free form. Serum glutamate pyruvate transaminase and alkaline phosphatase levels were increased in mice treated with free 32; this pattern was not observed for its liposomal and niosomal forms. Moreover, kidney function evaluations by measuring creatinine and urea levels pointed no toxicity for both vesicular forms. Histological assessment of the spleen also showed no apparent toxicity when treated with free, liposomal, and niosomal 32 (Medda et al. 1999).

Lantana montevidensis (Spreng.) Briq. (Verbenaceae) roots are another convenient source of iridoid glucosides. This perennial herb is native to Brazil and Uruguay, and possesses a variety of biological properties. 6-O- $\beta$-D-xylopyranoside-shanzhiside methyl ester (33), shanzhiside methyl ester (34), lamalbid (35), geniposidic acid (36), and theveside (37) (Fig. 9) were isolated and assayed against $L$. donovani promastigote and amastigote forms. Unfortunately, none 
Fig. 8 Iridoids from $V$. jatamansi rhizomes (28-31); amarogentin (32), a secoiridoid glucoside found in $S$. chirata
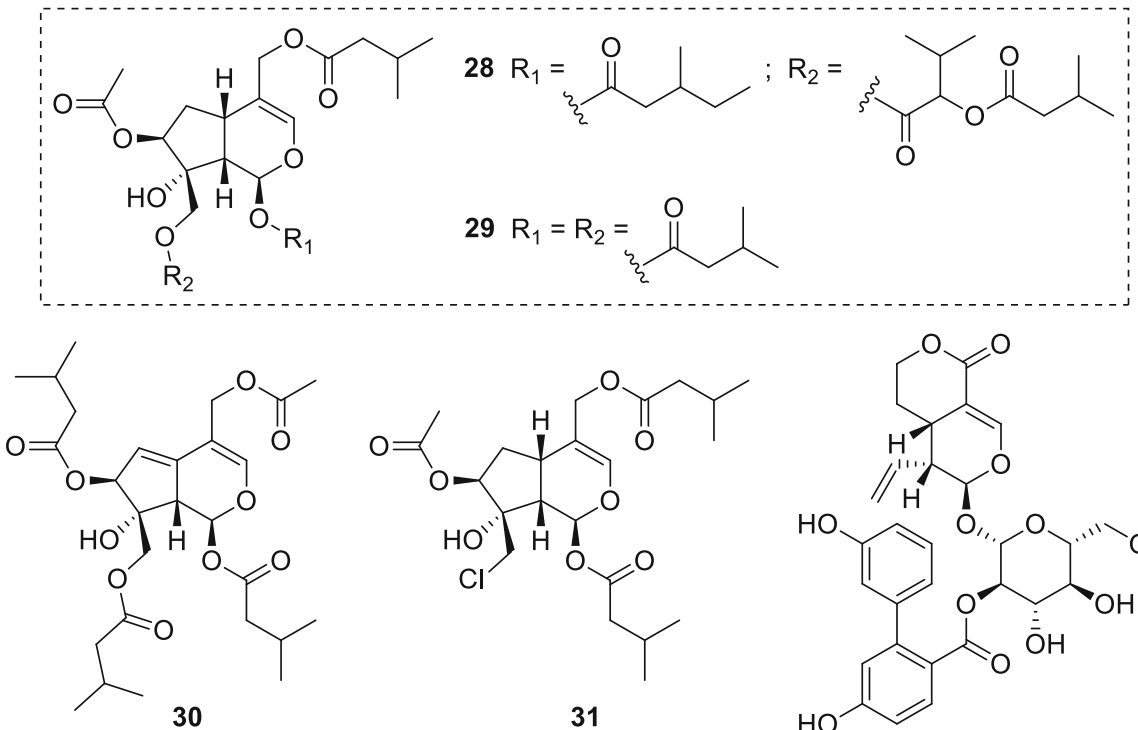<smiles>C=C[C@H]1[C@H](O[C@@H]2O[C@H](CO)[C@@H](O)[C@H](O)[C@H]2OC(=O)c2ccc(O)cc2-c2cccc(O)c2)OC=C2C(=O)OCC[C@]21C</smiles>

32



Fig. 9 Iridoid glucosides (33-37) from L. montevidensis; secoiridoids (38-40) isolated from N. indica leaves

of the isolates exhibited acitivity in the investigated concentrations (Mohamed et al. 2017).

The antiprotozoal potential of Nymphoides indica (L.) Kuntze (Menyanthaceae) phytochemicals was investigated. In this work, three secoiridoids were isolated from $N$. indica leaves: 7-epiexaltoside (38), $6^{\prime \prime}, 7^{\prime \prime}$-dihydro-7-epiexaltoside (39), and menthiafolin (40) (Fig. 9). The isolates 38-40 presented no activity against $L$. infantum amastigote forms in the assay $\left(\mathrm{IC}_{50}=>64 \mu \mathrm{M}\right)$. Regarding their toxicity, the compounds 38-40 showed no cytotoxicity ( $\mathrm{IC}_{50-}$ $>64 \mu \mathrm{M}$ ) against MRC-5 cells (human fetal lung fibroblasts) in the tested concentrations (Amin et al. 2016).
The iridoids ipolamiide (15) and (41-44) (Fig. 10) were isolated from three plant species: geniposide (41) and asperuloside (44) were obtained from Escalonia bifida Link \& Otto (Escalloniaceae); theveridoside (42) and 15 from Amphilophium crucigerum (L.) L.G.Lohmann (Bignoniaceae); galiridoside (43) from Angelonia integerrima Spreng. (Plantaginaceae). The aerial parts of all plants afforded the iridoid glucosides 15 and 41-44, which were screened against $L$. amazonensis promastigote forms. None of the isolates inhibited the parasites in the tested concentrations $(5-100 \mu \mathrm{M})$. Notwithstanding the compounds did not display leishmanicidal activity, in silico studies indicated that the low acitivity may be related to the 

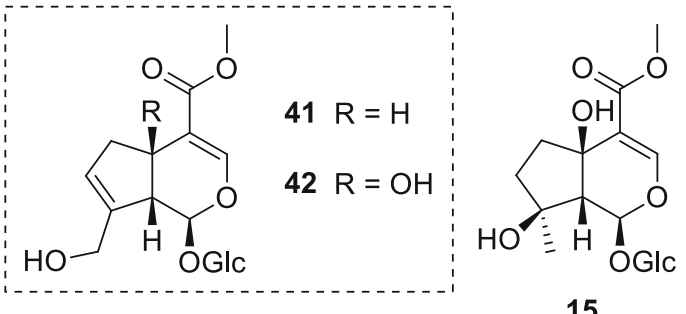

15

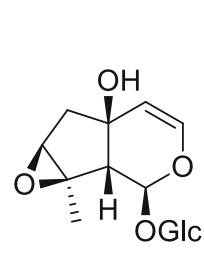

43

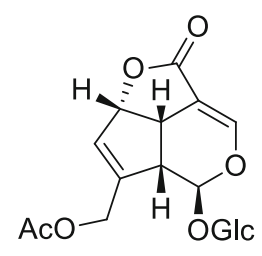

44

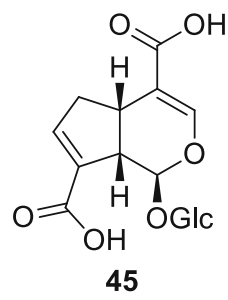

45
Fig. 10 Chemical structure of iridoids (15) and (41-44) isolated from assorted plants; ixoside (45), an iridoid glucoside found in T. stans stem barks

absence of bulky substituents attached to the iridoid scaffold (as it may be observed in plumericin 25). Structure-activity relationship and pharmacophore model studies also pointed the importance of structural features such as the cyclopentane[C]pyran ring and substituents at C-1/C-6 positions (Vendruscolo et al. 2019). In another study, the iridoid ixoside (45) (Fig. 10) was isolated from Tecoma stans var. velutina DC. (syn. Tecoma mollis Kunth) (Bignoniaceae) stem barks and evaluated against $L$. donovani promastigotes. At a dose of $80 \mu \mathrm{g} / \mathrm{mL}(206.01 \mu \mathrm{M}), \mathbf{4 5}$ was able to inhibit only $13 \%$ of parasites. Due to the low activity observed, the $\mathrm{IC}_{50}$ and $\mathrm{IC}_{90}$ values were not determined. Both reference drugs pentamidine (3) and amphotericin B (5) inhibited $100 \%$ of promastigote forms at the same conditions (Abdel-Mageed et al. 2012).

Some iridoid glucosides (Fig. 11) were isolated from Melampyrum arvense L. (Orobanchaceae) aerial parts and assayed against $L$. donovani axenic amastigotes. While aucubin (16) and mussaenoside (46) did not present activity in the assay, the carboxylcontaining iridoid mussaenosidic acid (47) displayed an $\mathrm{IC}_{50}$ of $88.1 \mu \mathrm{g} / \mathrm{mL}(234.08 \mu \mathrm{M})$. The parasites were more susceptible to melampyroside $(\mathbf{4 8})\left(\mathrm{IC}_{50-}\right.$ $=52.7 \mu \mathrm{g} / \mathrm{mL}, 116.99 \mu \mathrm{M})$ and 8-epi-loganin (49) $\left(\mathrm{IC}_{50}=41.1 \mu \mathrm{g} / \mathrm{mL}, 105.53 \mu \mathrm{M}\right)$. Cytotoxicity assay revealed that all isolates $(\mathbf{1 6}, \mathbf{4 6}-\mathbf{4 9})$ did not show toxicity against L6 cell lines in the tested concentrations; yet, further assessments are needed to verify their $\mathrm{CC}_{50}$ and SI towards parasites. It is noteworthy to mention that the aqueous extract, which yielded the iridoid glucosides, exhibited a half inhibitory concentration of $50.9 \mu \mathrm{g} / \mathrm{mL}$ against $L$. donovani axenic amastigotes (Kirmizibekmez et al. 2011).

Several species of the genus Vitex are employed in the traditional medicine. Curiously, only around 24 species among the 215 that compose the genus have been investigated for their phytochemical profile, thus being a potential taxon to be explored. Iridoid glucosides, along with flavonoids and diterpenoids, are one of the main constituents of this genus, contributing as secondary metabolites (Rani and Sharma 2013). The investigation of Vitex grandifolia Gürke (Lamiaceae) leaves resulted in the isolation of batsioside (50) and agnuside (51) (Fig. 11). These iridoid glucosides were screened against both $L$. donovani forms: promastigotes and amastigotes (axenic and in THP1 cells). Batsioside $\mathbf{5 0}$ displayed an $\mathrm{IC}_{50}$ value of $9.09 \mu \mathrm{g} / \mathrm{mL}(27.51 \mu \mathrm{M})$ against promastigote forms, while the axenic amastigotes were more resistant $\left(\mathrm{IC}_{50}=16.90 \mu \mathrm{g} / \mathrm{mL}, 51.16 \mu \mathrm{M}\right)$ and no activity was observed against intracellular amastigotes $\left(\mathrm{IC}_{50}=>25 \mu \mathrm{g} / \mathrm{mL}\right)$. Surprisingly, 51 demonstrated the opposite effect towards parasites. Whilst no activity was detected against the flagellated forms $\left(\mathrm{IC}_{50}=>25 \mu \mathrm{g} / \mathrm{mL},>53.59 \mu \mathrm{M}\right)$, both axenic and intracellular amastigotes were clearly more affected when treated with $\mathbf{5 1} \quad\left(\mathrm{IC}_{50}=16.98 \mu \mathrm{g} / \mathrm{mL}\right.$, $36.40 \mu \mathrm{M}$; and $5.38 \mu \mathrm{g} / \mathrm{mL}, 11.53 \mu \mathrm{M}$, respectively). These results prove how important is to comprise all Leishmania forms in the search of novel antileishmanial compounds, evidencing that the activity may vary between forms (Bello et al. 2018).

Past studies have reported the antiprotozoal potential of the genus Phlomis. The evaluation of extracts obtained from Turkish medicinal plants revealed the antileishmanial, antiplasmodial, and antitrypanosomal action of numerous Phlomis species (Tasdemir et al. 2005a, b). The phytoconstituents obtained from $P$. brunneogaleata Hub.-Mor. (Lamiaceae) aerial parts were evaluated against various protozoa, including $L$. donovani axenic amastigotes. Brunneogaleatoside (52) (Fig. 11), the only representative of the iridoid class in this study, presented an $\mathrm{IC}_{50}$ value of $4.7 \mu \mathrm{g} /$ $\mathrm{mL}(8.29 \mu \mathrm{M})$ against $L$. donovani axenic amastigotes. Furthermore, no cytotoxic effect in L6 cell lines 


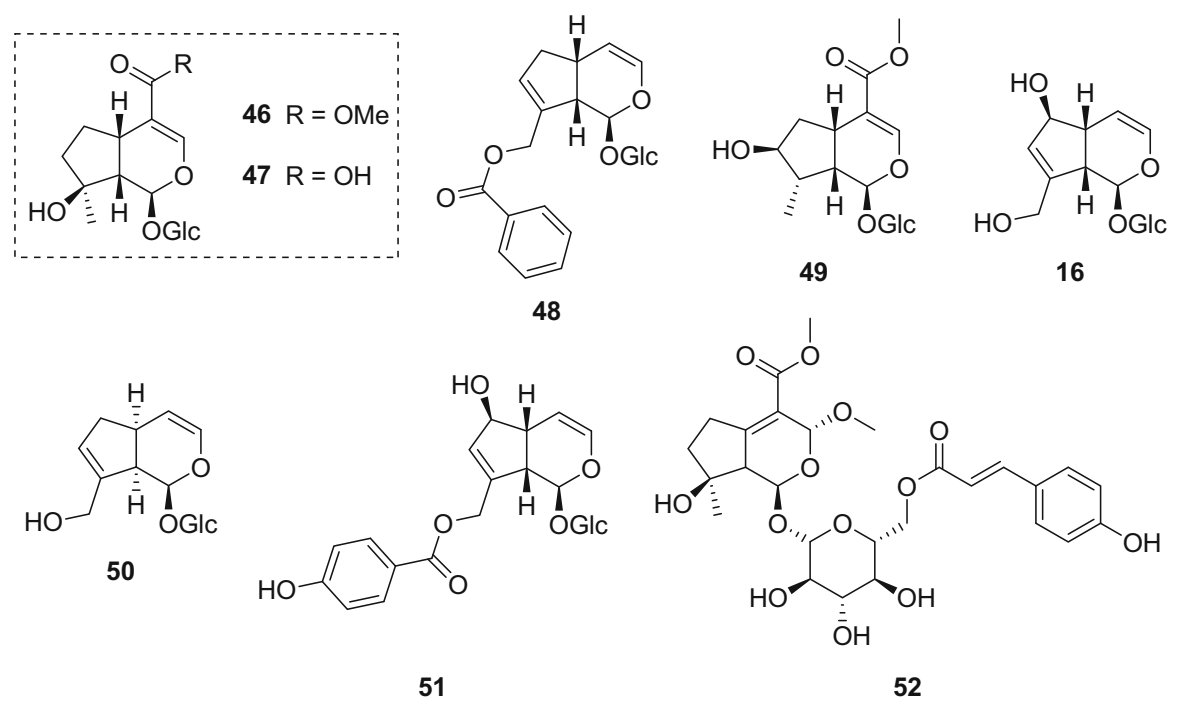

Fig. 11 Phytochemicals isolated from $M$. arvense: mussaenoside (46), mussaenosidic acid (47), melampyroside (48), 8-epi-loganin (49), and aucubin (16); batsioside (50) and

was observed in the concentration range tested $\left(\mathrm{IC}_{50-}\right.$ $=>90 \mu \mathrm{g} / \mathrm{mL},>158.85 \mu \mathrm{M})$. Even though $\mathbf{5 2}$ appears to be selective towards parasites, assessments against macrophage cell lines are crucial to verify its safety (Kirmizibekmez et al. 2004).

Scrophularia is another important genus known as a rich source of iridoids. A plethora of investigations have identified a range of biological properties for this genus, where the antiprotozoal activity may be highlighted (Pasdaran and Hamedi 2017). Harpagide (53) and its acetylated form acetylharpagide (54) (Fig. 12) were isolated from Scrophularia cryptophila Boiss. (Scrophulariaceae) and assayed against $L$. donovani axenic amastigotes. A significant leishmanicidal action was observed for $\mathbf{5 3}$, which exhibited an agnuside (51) are found in $V$. grandifolia leaves; brunneogaleatoside (52), an iridoid glucoside isolated from $P$. brunneogaleata

$\mathrm{IC}_{50}$ of $2.0 \mu \mathrm{g} / \mathrm{mL}(5.48 \mu \mathrm{M})$; however, a decrease in the activity was detected for $\mathbf{5 4}\left(\mathrm{IC}_{50}=6.9 \mu \mathrm{g} / \mathrm{mL}\right.$, $16.97 \mu \mathrm{M})$, indicating the importance of the hydrogen bond donor hydroxyl group at C-8. Fortunately, the toxicological assessment of iridoid glucosides $\mathbf{5 3}$ and 54 showed no cytotoxicity against L6 cell lines. The increased activity observed for $\mathbf{5 3}$ revealed its ability to maintain low cytotoxicity against L6 cell lines, which is a notable finding (Tasdemir et al. 2008). Both isolates 53 and $\mathbf{5 4}$ were also identified in Ajuga laxmannii (Murray) Benth. (Lamiaceae) aerial parts. In this report, among ten phytochemicals evaluated, $\mathbf{5 3}$ and 54 represented the most active isolates against $L$. donovani axenic amastigotes $\left(\mathrm{IC}_{50}=2.0 \mu \mathrm{g} / \mathrm{mL}\right.$,

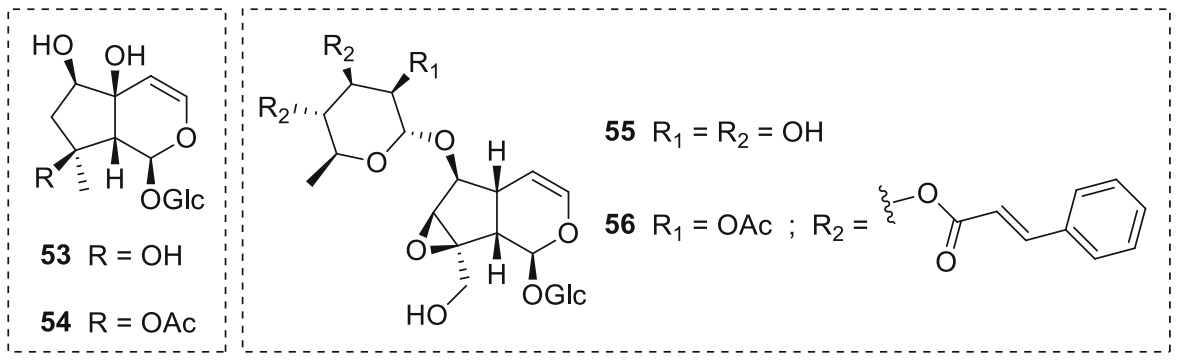

Fig. 12 Iridoids found in the genus Scrophularia: harpagide (53), acetylharpagide (54), 6- $O$ - $\alpha$-L-rhamnopyranosylcatalpol (55), and scropolioside B (56). Harpagide $\mathbf{5 3}$ and $\mathbf{5 4}$ also occur in A. laxmanni aerial parts 
$5.48 \mu \mathrm{M}$; and $6.9 \mu \mathrm{g} / \mathrm{mL}, 16.97 \mu \mathrm{M}$, respectively) (Atay et al. 2016).

The ethanolic extract of Scrophularia syriaca Benth. (Scrophulariaceae) aerial parts provided the iridoids $6-O-\alpha$-L-rhamnopyranosylcatalpol (55) and scropolioside B (56) (Fig. 12). These structurally diverse compounds were screened against the promastigote forms of $L$. major and L. mexicana. The isolate 55 was unable to inhibit the parasites of both Leishmania species. A remarkable enhance in the activity was observed for $\mathbf{5 6}$, which exhibited an $\mathrm{EC}_{50}$ of $6.70 \pm 0.18 \mu \mathrm{M}$ against $L$. major promastigotes and $8.34 \pm 1.70 \mu \mathrm{M}$ towards $L$. mexicana promastigotes. The presence of two trans-cinnamoyl groups attached to the rhamnose portion may be related to the improved activity of 56. This relation is based on the occurrence of free hydroxyl groups at the rhamnose moiety in 55, although further studies are needed to elucidate $\mathbf{5 6}$ mode of action (Alkhaldi et al. 2020).

Scrophularia lepidota Boiss. (Scrophulariaceae) is a source of multiple iridoid glucosides: aucubin (16), catalpol (57), 6- $O$-methylcatalpol (58), sinuatol (59), 6-O- $\beta$-D-xylopyranosylaucubin (60), ajugol (61), ajugoside (62), 3,4-dihydro-methylcatalpol (63), and scrolepidoside (64) (Fig. 13). With exception to 59 $\left(\mathrm{IC}_{50}=>100 \mu \mathrm{g} / \mathrm{mL},>203.05 \mu \mathrm{M}\right)$, all isolates presented activity against $L$. donovani axenic amastigotes in different degrees $\left(\mathrm{IC}_{50}=6.1-12.7 \mu \mathrm{g} / \mathrm{mL}\right.$, 12.11-33.56 $\mu \mathrm{M})$. Catalpol 57 and $\mathbf{5 8}$ displayed similar activity $\left(\mathrm{IC}_{50}=10.4 \mu \mathrm{g} / \mathrm{mL}, 28.70 \mu \mathrm{M}\right.$; and $8.3 \mu \mathrm{g} / \mathrm{mL}, \quad 22.05 \mu \mathrm{M}$, respectively), being the methoxylated form more active against parasites. The presence of a rhamnose at C- 6 was detrimental to the activity $\left(\mathrm{IC}_{50}=>100 \mu \mathrm{g} / \mathrm{mL},>203.05 \mu \mathrm{M}\right)$, as may be observed in 59. On the other hand, the iridoid containing a xylopyranosyl group at the same position, 60, exhibited an $\mathrm{IC}_{50}$ value of $8.5 \mu \mathrm{g} / \mathrm{mL}$ $(17.76 \mu \mathrm{M})$. Ajugol 61, 62, and 63 inhibited half of parasites at a concentration of $7.2 \mu \mathrm{g} / \mathrm{mL}(20.66 \mu \mathrm{M})$, $8.5 \mu \mathrm{g} / \mathrm{mL}(21.77 \mu \mathrm{M})$, and $12.7 \mu \mathrm{g} / \mathrm{mL}(33.56 \mu \mathrm{M})$, respectively. The most active isolate was $\mathbf{6 4}$, which presented an $\mathrm{IC}_{50}$ of $6.1 \mu \mathrm{g} / \mathrm{mL}(12.11 \mu \mathrm{M})$. Intriguingly, 64 contains the deoxy sugar rhamnose at C-6, being structurally similar to the inactive 59. The bulky group attached at the rhamnose moiety may be related to the enhanced leishmanicidal action of 64. Moreover, L6 cell lines were not affected when treated with the isolated iridoid glucosides in the tested concentrations. Each isolate presents diverse structural features, which may contribute to additional toxicological and mechanism of action studies. In this assay, 16 showed activity towards $L$. donovani axenic amastigotes $\left(\mathrm{IC}_{50}=10.9 \mu \mathrm{g} / \mathrm{mL}, 31.47 \mu \mathrm{M}\right)$ (Tasdemir et al. 2005a, b), while in the previously mentioned study no activity was observed (Kirmizibekmez et al. 2011). This inconsistence may be related to the strain employed, conferring distinct results. Each strain has its peculiarities; therefore, the parasites may present different susceptibilities when exposed to the same compound.

Picroliv, a standardized fraction of Picrorhiza kurroa Royle ex Benth. (Plantaginaceae) roots and rhizomes ethanolic extracts, has been attracting substantial attention in the past decades owing to its immunomodulatory and hepatoprotective activities. The main constituents of picroliv are picroside I (65) and kutkoside (66), composing a mixture in a ratio of 1:1.5 (Fig. 14). Presented as a yellow solid, picroliv

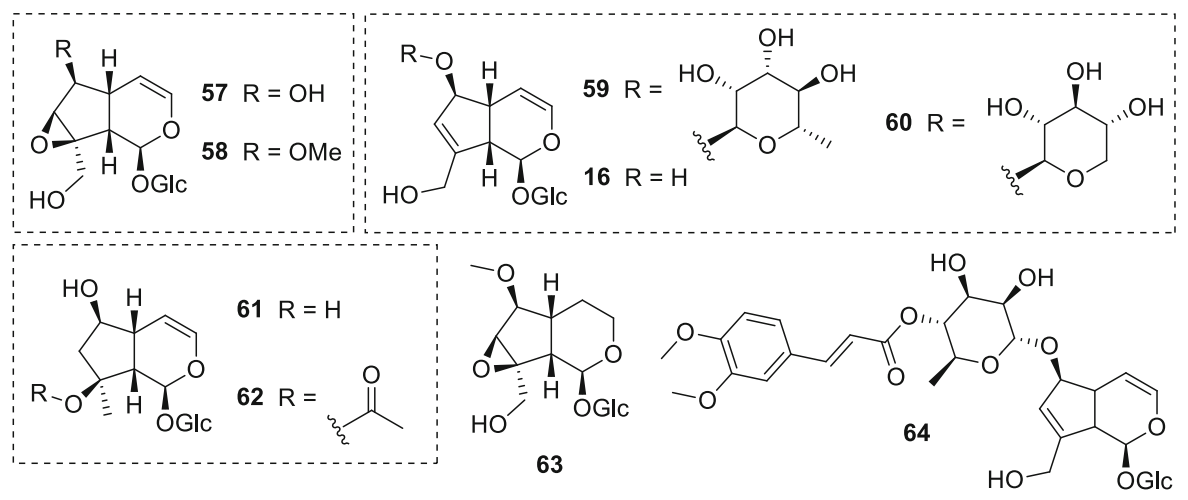

Fig. 13 Scrophularia lepidota iridoids: aucubin (16), catalpol (57), 6-O-methylcatalpol (58), sinuatol (59), 6- $O$ - $\beta$-D-xylopyranosylaucubin (60), ajugol (61), ajugoside (62), 3,4-dihydro-methylcatalpol (63), and scrolepidoside (64) 
Fig. 14 Picroliv is a standardized fraction of $P$. kurroa (Plantaginaceae) roots and rhizomes ethanolic extracts. It consists of a picroside I (65) and kutkoside (66) mixture $(1: 1.5)$

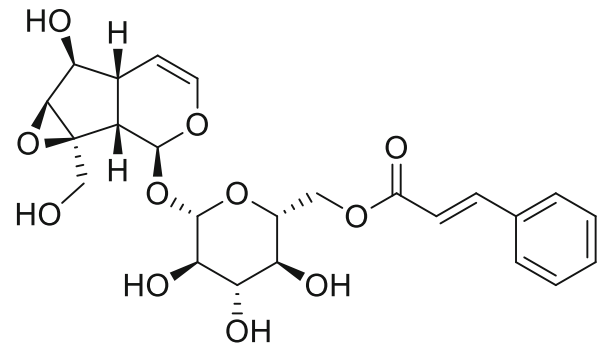

65<smiles>COc1cc(C(=O)OC[C@]23O[C@H]2[C@@H](O)[C@H]2C=CO[C@@H](O[C@@H]4O[C@H](CO)[C@@H](O)[C@H](O)[C@H]4O)[C@H]2[C@H]3O)ccc1O</smiles>

66 has already been administered in humans, and no serious adverse effects were observed. As a result, this promising mixture of iridoids has already completed phase I and II clinical trials aiming to assess its safety profile (Verma et al. 2009; Girish and Pradhan 2008).

Back in 1992, a study reported the ability of picroliv to enhance non-specific immune response in hamsters infected with L. donovani, the causative agent of VL. The activation of both macrophages and splenocytes induced by picroliv clearly played a pivotal role in the parasite burden decrease. Indeed, the iridoid mixture was able to significantly reduce the number of amastigotes per infected macrophage in the spleen, bone marrow, and liver. This protective action was a remarkable finding, considering macrophages are responsible for the host's first line defense against pathogens. In fact, Leishmania parasites are known for their capacity to modulate the host's immune system and to establish within macrophages, evading immune responses through complex mechanisms and hence persisting their survival. VL is a complicated clinical manifestation characterized by the suppression of the host's immune response by parasites; thus, the immunostimulant action of picroliv may contribute to parasite elimination by enhancing the efficacy of currently employed antileishmanial drugs (Puri et al. 1992).

Further studies were conducted in order to evaluate the efficacy of standard drugs (e.g., sodium stibogluconate $\mathbf{1}$ and miltefosine $\mathbf{4}$ ) in combination with picroliv. The premise of employing picroliv as an adjunct is fundamentally based on its immunostimulant and protective actions, since this mixture of iridoids possesses negligible antileishmanial activity.

The combination of sodium stibogluconate (1) with picroliv afforded positive results in $L$. donovaniinfected golden hamsters (Mesocricetus auratus).
Picroliv in combination with $\mathbf{1}$ presented superior efficacy in comparison to the standard drug alone, significantly reducing the parasite burden in golden hamsters. Not only picroliv was able to enhance the effectiveness of $\mathbf{1}$ but it also showed hepatoprotective action by significantly preventing the alteration of important enzymatic markers (Mittal et al. 1998).

Miltefosine (4) was a breakthrough in leishmaniasis treatment, being the first orally available drug. As mentioned before, there are some limitations concerning 4 use. In addition to important adverse effects, its long half-life may promote the emergence of resistance. Considering all these aspects, an investigation was conducted to verify the efficacy of $\mathbf{4}$ in suboptimal doses in combination with picroliv in golden hamsters. On day 7 after treatment termination, the in vivo analysis revealed that the $\mathbf{4}$ and picroliv combination was evidently more effective (84\%) than 4 alone $(45 \%)$. A posterior analysis on day 28 still conferred a better efficacy for the combination in reducing the parasite burden $(64 \%)$, in comparison to the standard drug alone (32\%). Hence, this combination may contribute as a new treatment regimen aiming to reduce the recommended dose of $\mathbf{4}$ in VL treatment (Gupta et al. 2005). Concomitant administration of $\mathbf{4}$, paromomycin (6), and picroliv has also proved to be fruitful. The parasite load in hamsters infected with $L$. donovani was significantly reduced $(96.6 \%)$ when treated with all three components. This improved efficacy was higher than any possible combination investigated. For instance, $\mathbf{4}$ and $\mathbf{6}$ co-administered resulted in $84.5 \%$ of parasite inhibition. The phagocytic activity of macrophages was improved as well, along with higher lymphocyte proliferation (Sane et al. 2011).

The repurpose of azole antifungal drugs for leishmaniasis treatment has been studied for several 
decades (Emami et al. 2017). The efficacy of miltefosine (4) and fluconazole combination therapy at their less toxic doses was evaluated with and without picroliv in L. donovani-infected golden hamsters. The employment of picroliv undoubtedly enhanced the efficacy of $\mathbf{4}$ and fluconazole combination, reducing parasite burden from 77 to $88 \%$. The immunomodulatory activity of picroliv has also played an important role by upregulating cell-mediated immunity response (Shakya et al. 2011a, b). In a similar study, the efficacy of ketoconazole and $\mathbf{4}$ combination (at their suboptimal doses) co-administered with picroliv was assessed. Golden hamsters were infected with $L$. donovani parasites, providing a VL model. The addition of picroliv increased the antileishmanial efficacy of $\mathbf{4}$ and ketoconazole combination from 72 to $82 \%$. Cell-mediated immune response was also enhanced with picroliv adding, evidencing the immunostimulant action of this mixture of iridoids (Shakya et al. 2011a, b).

Table 1 summarizes all studies dedicated to the antileishmanial potential of the iridoid class discussed in this review. It comprises 32 publications from 1991 to 2020, 52 substances, 22 plants, and investigations involved. For a better experience, we recommend using (Fig. 15) as a supplement to identify which iridoids and Leishmania spp. have been most investigated. $\mathrm{IC}_{50}$ values were standardized in $\mu \mathrm{M}$.

\section{Concluding remarks and prospects}

The data shown in this review indicate that this class of compounds deserves greater attention concerning antileishmanial activity. Iridoids of different structures should be analyzed in order to find more active compounds and also to outline a mechanism of action profile. Mechanistic studies have already pointed apoptotic, immunomodulatory, and protective properties for iridoids with assorted structural patterns. Among these substances, arbortristoside A (17) (Fig. 5) showed interesting activity in in vivo $L$. donovani VL model studies (Tandon et al. 1991) and inhibitory capacity towards TryR, a validated trypanosomatid drug target (Shukla et al. 2011). Previous works reported immunomodulatory properties for $\mathbf{1 7}$ in mice infected with Candida albicans (Khan et al. 1995); moreover, 17 has exhibited anti-inflammatory, anticancer, antiallergic, and antiviral activities
(Agrawal and Pal 2013). Amarogentin (32) (Fig. 8) also deserves attention due to its inhibitory activity against L. donovani DNA topoisomerase I and encouraging in vivo results (Medda et al. 1999). Amarogentin 32 pharmacological potential is not restricted to its antileishmanial activity; 32 showed anticarcinogenic properties through mechanisms involving apoptosis and cell cycle modulation (Pal et al 2012). Even though oleuropein (21) (Fig. 6) exhibited negligible in vitro activity against $L$. donovani (Kyriazis et al. 2013) and L. major parasites (Elamin and AL-Maliki 2014), immunomodulatory properties were observed through in vivo assessments. The persistent leishmanicidal action attributed to $\mathbf{2 1}$ in in vivo $L$. donovani VL model studies highlights its ability to enhance the host's immune response, countering its suppression by parasites (Kyriazis et al. 2013, 2016). This could be an interesting approach to develop new VL treatment regimens and enhance the efficacy of the available drugs. Indeed, this strategy was investigated by employing picroliv, a mixture of iridoids (Fig. 14), in combination with antileishmanial drugs (Puri et al. 1992; Mittal et al. 1998; Gupta et al. 2005; Sane et al. 2011; Shakya et al. 2011a, b; Shakya et al. 2011a, b). Picroliv is still vastly studied; a recent review discussed some of its reported activities, which include antitumor, anti-inflammatory, and hepatoprotective properties (Guo et al 2019). We highlight the immunomodulatory potential the iridoid class seems to possess in in vivo VL model studies, which may be a convenient approach to improve current antileishmanial treatments. Also, the immunomodulatory investigation of isolates or standardized extract fractions containing iridoids, as picroliv, could be an attractive strategy for further investigations.

Notwithstanding that some iridoids, as highlighted above, possess an antileishmanial potential and apparent safety, investigations seem restricted to academic environments. For instance, picroliv (Fig. 14) showed encouraging results improving the efficacy of currently employed drugs, even at suboptimal doses. Still, the last article published involving picroliv on in vivo VL studies was in 2011. Leishmaniasis is a complex disease. Both in vitro and in vivo studies require high costs due to the Leishmania spp. digenetic life cycle (Fig. 1). The NTD status leishmaniasis burdens may explain the recurrent lack of funds. Academic research generally relies on funding, and without financial 
Table 1 Summary of iridoids assayed against Leishmania spp. parasites

\begin{tabular}{|c|c|c|c|c|}
\hline Entry & Compound name & Activity & $\begin{array}{l}\text { Plant name and } \\
\text { part }\end{array}$ & References \\
\hline$(15)$ & Ipolamiide & L. amazonensis promastigotes $\left(\mathrm{IC}_{50}=>100 \mu \mathrm{M}\right)$ & $\begin{array}{l}\text { Amphilophium } \\
\text { crucigerum } \\
\text { aerial parts }\end{array}$ & $\begin{array}{l}\text { Vendruscolo } \\
\text { et al. (2019) }\end{array}$ \\
\hline \multirow[t]{2}{*}{ (16) } & \multirow[t]{2}{*}{ Aucubin } & $\begin{array}{l}\text { L. donovani axenic amastigotes } \\
\qquad\left(\mathrm{IC}_{50}=>259.86 \mu \mathrm{M}\right)^{\mathrm{a}}\end{array}$ & $\begin{array}{l}\text { Melampyrum } \\
\text { arvense aerial } \\
\text { parts }^{\mathrm{a}}\end{array}$ & $\begin{array}{l}\text { Kirmizibekmez } \\
\text { et al. }(2011)^{\mathrm{a}}\end{array}$ \\
\hline & & L. donovani axenic amastigotes $\left(\mathrm{IC}_{50}=31.47 \mu \mathrm{M}\right)^{\mathrm{b}}$ & $\begin{array}{l}\text { Scrophularia } \\
\quad \text { lepidota } \text { roots }^{\mathrm{b}}\end{array}$ & $\begin{array}{l}\text { Tasdemir et al. } \\
(2005 \mathrm{a}, \mathrm{b})^{\mathrm{b}}\end{array}$ \\
\hline \multirow[t]{5}{*}{ (17) } & \multirow[t]{5}{*}{ Arbortristoside A } & $\begin{array}{l}\text { L. donovani amastigotes inhibition }(45.83 \pm 7.21 \% \text { at } \\
52.95 \mu \mathrm{M} ; 64.58 \pm 3.60 \% \text { at } 176.55 \mu \mathrm{M})^{\mathrm{a}}\end{array}$ & \multirow[t]{17}{*}{$\begin{array}{l}\text { Nyctanthes arbor- } \\
\text { tristis seeds }\end{array}$} & $\begin{array}{l}\text { Tandon et al. } \\
(1991)^{\mathrm{a}}\end{array}$ \\
\hline & & in vivo $L$. donovani $\mathrm{VL}$ model studies ${ }^{\mathrm{a}}$ & & $\begin{array}{l}\text { Shukla et al. } \\
(2011)^{\mathrm{b}}\end{array}$ \\
\hline & & TryR inhibition $\left(\mathrm{IC}_{50}=2.65 \pm 0.05 \mu \mathrm{M}\right)^{\mathrm{b}}$ & & $\begin{array}{l}\text { Shukla et al. } \\
(2012)^{\mathrm{C}}\end{array}$ \\
\hline & & L. donovani promastigotes $\left(\mathrm{IC}_{50}=3.264 \pm 0.05 \mu \mathrm{M}\right)^{\mathrm{c}}$ & & \\
\hline & & $\begin{array}{l}\text { L. donovani axenic amastigotes } \\
\left(\mathrm{IC}_{50}=7.26 \pm 0.05 \mu \mathrm{M}\right)^{\mathrm{c}}\end{array}$ & & \\
\hline \multirow[t]{2}{*}{ (18) } & \multirow[t]{2}{*}{ Arbortristoside B } & $\begin{array}{l}\text { L. donovani amastigotes inhibition }(25.12 \pm 7.11 \% \text { at } \\
51.32 \mu \mathrm{M} ; 47.34 \pm 9.12 \% \text { at } 102.64 \mu \mathrm{M})^{\mathrm{a}}\end{array}$ & & \\
\hline & & in vivo $L$. donovani $\mathrm{VL}$ model studies ${ }^{\mathrm{a}}$ & & \\
\hline \multirow[t]{5}{*}{ (19) } & \multirow[t]{5}{*}{ Arbortristoside $\mathrm{C}$} & $\begin{array}{l}\text { L. donovani amastigotes inhibition }(67.43 \pm 4.02 \% \text { at } \\
54.29 \mu \mathrm{M} \text {; toxic to macrophages at } 108.59 \mu \mathrm{M})^{\mathrm{a}}\end{array}$ & & \\
\hline & & in vivo $L$. donovani $\mathrm{VL}$ model studies ${ }^{\mathrm{a}}$ & & \\
\hline & & TryR inhibition $\left(\mathrm{IC}_{50}=2.29 \pm 0.03 \mu \mathrm{M}\right)^{\mathrm{b}}$ & & \\
\hline & & L. donovani promastigotes $\left(\mathrm{IC}_{50}=3.504 \pm 0.04 \mu \mathrm{M}\right)^{\mathrm{c}}$ & & \\
\hline & & $\begin{array}{l}\text { L. donovani axenic amastigotes } \\
\left(\mathrm{IC}_{50}=7.63 \pm 0.05 \mu \mathrm{M}\right)^{\mathrm{c}}\end{array}$ & & \\
\hline \multirow[t]{5}{*}{ (20) } & \multirow[t]{5}{*}{$6 \beta$-hydroxyloganin } & $\begin{array}{l}\text { L. donovani amastigotes inhibition }(65.77 \pm 4.56 \% \text { at } \\
73.82 \mu \mathrm{M} \text {; toxic to macrophages at } 147.64 \mu \mathrm{M})^{\mathrm{a}}\end{array}$ & & \\
\hline & & in vivo $L$. donovani $\mathrm{VL}$ model studies ${ }^{\mathrm{a}}$ & & \\
\hline & & TryR inhibition $\left(\mathrm{IC}_{50}=4.74 \pm 0.05 \mu \mathrm{M}\right)^{\mathrm{b}}$ & & \\
\hline & & L. donovani promastigotes $\left(\mathrm{IC}_{50}=5.016 \pm 0.05 \mu \mathrm{M}\right)^{\mathrm{c}}$ & & \\
\hline & & $\begin{array}{l}\text { L. donovani axenic amastigotes } \\
\left(\mathrm{IC}_{50}=9.00 \pm 0.03 \mu \mathrm{M}\right)^{\mathrm{c}}\end{array}$ & & \\
\hline \multirow[t]{6}{*}{$(21)$} & \multirow[t]{6}{*}{ Oleuropein } & L. donovani promastigotes $\left(\mathrm{IC}_{50}=142.82 \pm 19 \mu \mathrm{M}\right)^{\mathrm{a}}$ & \multirow[t]{6}{*}{$\begin{array}{l}\text { Olea europaea } \\
\text { leaves }{ }^{\mathrm{a}, \mathrm{b}, \mathrm{c}}\end{array}$} & $\begin{array}{l}\text { Kyriazis et al. } \\
(2013)^{\text {a }}\end{array}$ \\
\hline & & L. donovani amastigotes $\left(\mathrm{IC}_{50}=203.51 \pm 59 \mu \mathrm{M}\right)^{\mathrm{a}}$ & & $\begin{array}{l}\text { Kyriazis et al. } \\
(2016)^{\mathrm{b}}\end{array}$ \\
\hline & & $\begin{array}{l}\text { L. infantum promastigotes } \\
\qquad\left(\mathrm{IC}_{50}=268.26 \mu \mathrm{M} \pm 38 \mu \mathrm{M}\right)^{\mathrm{a}}\end{array}$ & & $\begin{array}{l}\text { Elamin and AL- } \\
\text { Maliki } \\
(2014)^{\mathrm{c}}\end{array}$ \\
\hline & & L. major promastigotes $\left(\mathrm{IC}_{50}=260.86 \pm 42 \mu \mathrm{M}\right)^{\mathrm{a}}$ & & \\
\hline & & in vivo $L$. donovani $\mathrm{VL}$ model studies ${ }^{\mathrm{a}, \mathrm{b}}$ & & \\
\hline & & $\begin{array}{l}\text { L. major promastigotes inhibition }(88.5 \% \text { at } \\
462.52 \mu \mathrm{M})^{\mathrm{c}}\end{array}$ & & \\
\hline$(22)$ & Molucidin & L. hertigi promastigotes $\left(\mathrm{IC}_{50}=4.24 \mu \mathrm{M}\right)^{\mathrm{a}}$ & $\begin{array}{l}\text { Morinda lucida } \\
\text { leaves }^{\mathrm{a}, \mathrm{b}}\end{array}$ & $\begin{array}{l}\text { Amoa- } \\
\text { Bosompem } \\
\text { et al. }(2016)^{\mathrm{a}}\end{array}$ \\
\hline
\end{tabular}


Table 1 continued

\begin{tabular}{|c|c|c|c|c|}
\hline Entry & Compound name & Activity & $\begin{array}{l}\text { Plant name and } \\
\text { part }\end{array}$ & References \\
\hline & & L. enriettii promastigotes $(\mathrm{MIC}=4.17 \mu \mathrm{M})^{\mathrm{a}}$ & & $\begin{array}{l}\text { Azerigyik et al. } \\
(2018)^{\mathrm{b}}\end{array}$ \\
\hline & & L. donovani promastigotes $\left(\mathrm{IC}_{50}=2.94 \pm 0.60 \mu \mathrm{M}\right)^{\mathrm{b}}$ & & \\
\hline & & L. major promastigotes $\left(\mathrm{IC}_{50}=1.85 \pm 0.20 \mu \mathrm{M}\right)^{\mathrm{b}}$ & & \\
\hline \multirow[t]{2}{*}{$(23)$} & ML-2-3 & L. hertigi promastigotes $\left(\mathrm{IC}_{50}=>50 \mu \mathrm{M}\right)^{\mathrm{a}}$ & & \\
\hline & & L. enriettii promastigotes $(\mathrm{MIC}=>50 \mu \mathrm{M})^{\mathrm{a}}$ & & \\
\hline \multirow[t]{4}{*}{ (24) } & ML-F52 & L. hertigi promastigotes $\left(\mathrm{IC}_{50}=3.38 \mu \mathrm{M}\right)^{\mathrm{a}}$ & & \\
\hline & & L. enriettii promastigotes $(\mathrm{MIC}=2.60 \mu \mathrm{M})^{\mathrm{a}}$ & & \\
\hline & & L. donovani promastigotes $\left(\mathrm{IC}_{50}=0.91 \pm 0.50 \mu \mathrm{M}\right)^{\mathrm{b}}$ & & \\
\hline & & L. major promastigotes $\left(\mathrm{IC}_{50}=1.77 \pm 0.20 \mu \mathrm{M}\right)^{\mathrm{b}}$ & & \\
\hline \multirow[t]{6}{*}{$(25)$} & Plumericin & L. donovani promastigotes $\left(\mathrm{IC}_{50}=3.17 \pm 0.12 \mu \mathrm{M}\right)^{\mathrm{a}}$ & $\begin{array}{l}\text { Plumeria rubra } \\
\text { stem barks }^{\mathrm{a}}\end{array}$ & $\begin{array}{l}\text { Sharma et al. } \\
(2011)^{\mathrm{a}}\end{array}$ \\
\hline & & L. donovani amastigotes $\left(\mathrm{IC}_{50}=1.41 \pm 0.03 \mu \mathrm{M}\right)^{\mathrm{a}}$ & $\begin{array}{l}\text { Himatanthus } \\
\text { sucuuba } \text { stem } \\
\text { barks }^{\text {b }}\end{array}$ & $\begin{array}{l}\text { Castillo et al. } \\
(2007)^{\mathrm{b}}\end{array}$ \\
\hline & & L. amazonensis axenic amastigotes $\left(\mathrm{IC}_{50}=0.21 \mu \mathrm{M}\right)^{\mathrm{b}}$ & $\begin{array}{l}\text { Allamanda } \\
\text { schottii roots }^{\mathrm{c}}\end{array}$ & $\begin{array}{l}\text { Filho et al. } \\
\qquad(2013)^{\mathrm{c}}\end{array}$ \\
\hline & & L. amazonensis amastigotes $\left(\mathrm{IC}_{50}=0.9 \mu \mathrm{M}\right)^{\mathrm{b}}$ & & \\
\hline & & $\begin{array}{l}\text { L. amazonensis promastigotes } \\
\left(\mathrm{IC}_{50}=1.03 \pm 0.24 \mu \mathrm{M}\right)^{\mathrm{c}}\end{array}$ & & \\
\hline & & $\begin{array}{l}\text { L. braziliensis promastigotes } \\
\quad\left(\mathrm{IC}_{50}=0.13 \pm 0.02 \mu \mathrm{M}\right)^{\mathrm{c}}\end{array}$ & & \\
\hline \multirow[t]{3}{*}{ (26) } & Isoplumericin & L. donovani promastigotes $\left(\mathrm{IC}_{50}=7.2 \pm 0.08 \mu \mathrm{M}\right)^{\mathrm{a}}$ & $\begin{array}{l}\text { Plumeria rubra } \\
\text { stem barks }^{\mathrm{a}}\end{array}$ & $\begin{array}{l}\text { Sharma et al. } \\
(2011)^{\mathrm{a}}\end{array}$ \\
\hline & & L. donovani amastigotes $\left(\mathrm{IC}_{50}=4.1 \pm 0.02 \mu \mathrm{M}\right)^{\mathrm{a}}$ & $\begin{array}{l}\text { Himatanthus } \\
\text { sucuuba } \text { stem } \\
\text { barks }^{\text {b }}\end{array}$ & $\begin{array}{l}\text { Castillo et al. } \\
(2007)^{\mathrm{b}}\end{array}$ \\
\hline & & L. amazonensis axenic amastigotes $\left(\mathrm{IC}_{50}=0.28 \mu \mathrm{M}\right)^{\mathrm{b}}$ & & \\
\hline \multirow[t]{2}{*}{$(27)$} & Plumieride & L. amazonensis promastigotes $\left(\mathrm{IC}_{50}=>212.57 \mu \mathrm{M}\right)$ & $\begin{array}{l}\text { Allamanda } \\
\text { schottii roots }\end{array}$ & $\begin{array}{l}\text { Filho et al. } \\
\text { (2013) }\end{array}$ \\
\hline & & $\begin{array}{l}\text { L. braziliensis promastigotes } \\
\left(\mathrm{IC}_{50}=45.27 \pm 5.95 \mu \mathrm{M}\right)\end{array}$ & & \\
\hline$(28)$ & Valepotriates & L. major promastigotes $\left(\mathrm{IC}_{50}=2.96 \mu \mathrm{M}\right)$ & $\begin{array}{l}\text { Valeriana } \\
\text { jatamansi } \\
\text { rhizomes }\end{array}$ & $\begin{array}{l}\text { Glaser et al. } \\
(2015)\end{array}$ \\
\hline (29) & & L. major promastigotes $\left(\mathrm{IC}_{50}=1.52 \mu \mathrm{M}\right)$ & & \\
\hline$(30)$ & & L. major promastigotes $\left(\mathrm{IC}_{50}=1.7 \mu \mathrm{M}\right)$ & & \\
\hline$(31)$ & & L. major promastigotes $\left(\mathrm{IC}_{50}=4.98 \mu \mathrm{M}\right)$ & & \\
\hline \multirow[t]{2}{*}{$(32)$} & Amarogentin & L. donovani DNA topoisomerase I enzyme inhibitor ${ }^{\mathrm{a}}$ & $\begin{array}{l}\text { Swertia chirata } \\
\text { aerial parts }\end{array}$ & $\begin{array}{l}\text { Ray et al. } \\
(1996)^{\mathrm{a}}\end{array}$ \\
\hline & & in vivo $L$. donovani $\mathrm{VL}$ model studies ${ }^{\mathrm{b}}$ & & $\begin{array}{l}\text { Medda et al. } \\
(1999)^{\mathrm{b}}\end{array}$ \\
\hline$(33)$ & $\begin{array}{l}\text { 6-O- } \beta \text {-D-xylopyranoside- } \\
\text { shanzhiside methyl ester }\end{array}$ & $\begin{array}{l}\text { None of the compounds showed activity towards } L \text {. } \\
\text { donovani promastigotes and axenic/intracellular } \\
\text { amastigotes }\end{array}$ & $\begin{array}{l}\text { Lantana } \\
\text { montevidensis } \\
\text { roots }\end{array}$ & $\begin{array}{l}\text { Mohamed et al. } \\
\text { (2017) }\end{array}$ \\
\hline (34) & Shanzhiside methyl ester & & & \\
\hline$(35)$ & Lamalbid & & & \\
\hline (36) & Geniposidic acid & & & \\
\hline
\end{tabular}


Table 1 continued

\begin{tabular}{|c|c|c|c|c|}
\hline Entry & Compound name & Activity & $\begin{array}{l}\text { Plant name and } \\
\text { part }\end{array}$ & References \\
\hline$(37)$ & Theveside & & & \\
\hline (38) & 7-epiexaltoside & L. infantum amastigotes $\left(\mathrm{IC}_{50}=>64 \mu \mathrm{M}\right)$ & $\begin{array}{l}\text { Nymphoides } \\
\text { indica leaves }\end{array}$ & $\begin{array}{l}\text { Amin et al. } \\
\text { (2016) }\end{array}$ \\
\hline (39) & $\begin{array}{l}6^{\prime \prime}, 7^{\prime \prime} \text {-dihydro-7- } \\
\text { epiexaltoside }\end{array}$ & L. infantum amastigotes $\left(\mathrm{IC}_{50}=>64 \mu \mathrm{M}\right)$ & & \\
\hline$(40)$ & Menthiafolin & L. infantum amastigotes $\left(\mathrm{IC}_{50}=>64 \mu \mathrm{M}\right)$ & & \\
\hline$(41)$ & Geniposide & L. amazonensis promastigotes $\left(\mathrm{IC}_{50}=>100 \mu \mathrm{M}\right)$ & $\begin{array}{l}\text { Escalonia bifida } \\
\text { aerial parts }\end{array}$ & $\begin{array}{l}\text { Vendruscolo } \\
\text { et al. (2019) }\end{array}$ \\
\hline$(42)$ & Theveridoside & & $\begin{array}{l}\text { Amphilophium } \\
\text { crucigerum } \\
\text { aerial parts }\end{array}$ & \\
\hline (43) & Galiridoside & & $\begin{array}{l}\text { Angelonia } \\
\text { integerrima } \\
\text { aerial parts }\end{array}$ & \\
\hline$(44)$ & Asperuloside & & $\begin{array}{l}\text { Escalonia bifida } \\
\text { aerial parts }\end{array}$ & \\
\hline$(45)$ & Ixoside & $\begin{array}{l}\text { L. donovani promastigotes ( } 13 \% \text { of inhibition at } \\
206.01 \mu \mathrm{M})\end{array}$ & $\begin{array}{l}\text { Tecoma stans } \\
\text { stem barks }\end{array}$ & $\begin{array}{l}\text { Abdel-Mageed } \\
\text { et al. (2012) }\end{array}$ \\
\hline$(46)$ & Mussaenoside & L. donovani axenic amastigotes $\left(\mathrm{IC}_{50}>230.54 \mu \mathrm{M}\right)$ & $\begin{array}{l}\text { Melampyrum } \\
\text { arvense aerial } \\
\text { parts }\end{array}$ & $\begin{array}{l}\text { Kirmizibekmez } \\
\text { et al. (2011) }\end{array}$ \\
\hline$(47)$ & Mussaenosidic acid & L. donovani axenic amastigotes $\left(\mathrm{IC}_{50}=234.08 \mu \mathrm{M}\right)$ & & \\
\hline$(48)$ & Melampyroside & L. donovani axenic amastigotes $\left(\mathrm{IC}_{50}=116.99 \mu \mathrm{M}\right)$ & & \\
\hline$(49)$ & 8-epi-loganin & L. donovani axenic amastigotes $\left(\mathrm{IC}_{50}=105.53 \mu \mathrm{M}\right)$ & & \\
\hline \multirow[t]{2}{*}{$(50)$} & Batsioside & L. donovani promastigotes $\left(\mathrm{IC}_{50}=27.51 \mu \mathrm{M}\right)$ & $\begin{array}{l}\text { Vitex grandifolia } \\
\text { leaves }\end{array}$ & $\begin{array}{l}\text { Bello et al. } \\
\text { (2018) }\end{array}$ \\
\hline & & L. donovani axenic amastigotes $\left(\mathrm{IC}_{50}=51.16 \mu \mathrm{M}\right)$ & & \\
\hline$(51)$ & Agnuside & $\begin{array}{l}\text { L. donovani promastigotes }\left(\mathrm{IC}_{50}=>53.59 \mu \mathrm{M}\right) \\
\text { L. donovani axenic amastigotes }\left(\mathrm{IC}_{50}=36.40 \mu \mathrm{M}\right) \\
\text { L. donovani amastigotes }\left(\mathrm{IC}_{50}=11.53 \mu \mathrm{M}\right)\end{array}$ & & \\
\hline$(52)$ & Brunneogaleatoside & L. donovani axenic amastigotes $\left(\mathrm{IC}_{50}=8.29 \mu \mathrm{M}\right)$ & $\begin{array}{l}\text { Phlomis } \\
\text { brunneogaleata } \\
\text { aerial parts }\end{array}$ & $\begin{array}{l}\text { Kirmizibekmez } \\
\text { et al. (2004) }\end{array}$ \\
\hline$(53)$ & Harpagide & L. donovani axenic amastigotes $\left(\mathrm{IC}_{50}=5.48 \mu \mathrm{M}\right)^{\mathrm{a}, \mathrm{b}}$ & $\begin{array}{l}\text { Scrophularia } \\
\text { cryptophila } \\
\text { aerial parts }\end{array}$ & $\begin{array}{l}\text { Atay et al. } \\
(2016)^{\mathrm{a}}\end{array}$ \\
\hline (54) & Acetylharpagide & L. donovani axenic amastigotes $\left(\mathrm{IC}_{50}=16.97 \mu \mathrm{M}\right)^{\mathrm{a}, \mathrm{b}}$ & $\begin{array}{l}\text { Ajuga laxmannii } \\
\text { aerial parts } \\
\text { b }\end{array}$ & $\begin{array}{l}\text { Atay et al. } \\
(2016)^{\mathrm{b}}\end{array}$ \\
\hline \multirow[t]{2}{*}{$(55)$} & $\begin{array}{l}\text { 6-O- } \alpha \text {-L- } \\
\text { rhamnopyranosylcatalpol }\end{array}$ & L. major promastigotes $\left(\mathrm{EC}_{50}=>100 \mu \mathrm{M}\right)$ & $\begin{array}{l}\text { Scrophularia } \\
\text { syriaca aerial } \\
\text { parts }\end{array}$ & $\begin{array}{l}\text { Alkhaldi et al. } \\
\text { (2020) }\end{array}$ \\
\hline & & L. mexicana promastigotes $\left(\mathrm{EC}_{50}=>100 \mu \mathrm{M}\right)$ & & \\
\hline$(56)$ & Scropolioside B & $\begin{array}{l}\text { L. major promastigotes }\left(\mathrm{EC}_{50}=6.70 \pm 0.18 \mu \mathrm{M}\right) \\
\text { L. mexicana promastigotes }\left(\mathrm{EC}_{50}=8.34 \pm 1.70 \mu \mathrm{M}\right)\end{array}$ & & \\
\hline$(57)$ & Catalpol & L. donovani axenic amastigotes $\left(\mathrm{IC}_{50}=28.70 \mu \mathrm{M}\right)$ & $\begin{array}{l}\text { Scrophularia } \\
\text { lepidota roots }\end{array}$ & $\begin{array}{l}\text { Tasdemir et al. } \\
(2005 \mathrm{a}, \mathrm{b})\end{array}$ \\
\hline$(58)$ & 6-O-methylcatalpol & L. donovani axenic amastigotes $\left(\mathrm{IC}_{50}=22.05 \mu \mathrm{M}\right)$ & & \\
\hline$(59)$ & Sinuatol & L. donovani axenic amastigotes $\left(\mathrm{IC}_{50}=>203.05 \mu \mathrm{M}\right)$ & & \\
\hline
\end{tabular}


Table 1 continued

\begin{tabular}{|c|c|c|c|c|}
\hline Entry & Compound name & Activity & $\begin{array}{l}\text { Plant name and } \\
\text { part }\end{array}$ & References \\
\hline$(60)$ & $\begin{array}{l}\text { 6- } O-\beta-\mathrm{D}- \\
\quad \text { xylopyranosylaucubin }\end{array}$ & L. donovani axenic amastigotes $\left(\mathrm{IC}_{50}=17.76 \mu \mathrm{M}\right)$ & & \\
\hline$(61)$ & Ajugol & L. donovani axenic amastigotes $\left(\mathrm{IC}_{50}=20.66 \mu \mathrm{M}\right)$ & & \\
\hline$(62)$ & Ajugoside & L. donovani axenic amastigotes $\left(\mathrm{IC}_{50}=21.77 \mu \mathrm{M}\right)$ & & \\
\hline$(63)$ & $\begin{array}{l}\text { 3,4-dihydro- } \\
\text { methylcatalpol }\end{array}$ & L. donovani axenic amastigotes $\left(\mathrm{IC}_{50}=33.56 \mu \mathrm{M}\right)$ & & \\
\hline$(64)$ & Scrolepidoside & L. donovani axenic amastigotes $\left(\mathrm{IC}_{50}=12.11 \mu \mathrm{M}\right)$ & & \\
\hline \multirow[t]{5}{*}{$(65)$} & Picroside I & $\begin{array}{l}\text { Picroliv consists of a } \mathbf{6 5} \text { and } \mathbf{6 6} \text { mixture }(1: 1.5) \text {. It } \\
\text { possesses immunomodulatory properties and } \\
\text { enhances antileishmanial drug efficacy in VL models }\end{array}$ & $\begin{array}{l}\text { Picrorhiza kurroa } \\
\text { roots and } \\
\text { rhizomes }\end{array}$ & $\begin{array}{l}\text { Puri et al. } \\
\text { (1992) }\end{array}$ \\
\hline & & & & $\begin{array}{l}\text { Mittal et al. } \\
\text { (1998) }\end{array}$ \\
\hline & & & & $\begin{array}{l}\text { Gupta et al. } \\
(2005)\end{array}$ \\
\hline & & & & $\begin{array}{l}\text { Sane et al. } \\
\text { (2011) }\end{array}$ \\
\hline & & & & $\begin{array}{c}\text { Shakya et al. } \\
(2011 \mathrm{a}, \mathrm{b})\end{array}$ \\
\hline$(66)$ & Kutkoside & & & $\begin{array}{c}\text { Shakya et al. } \\
(2011 \mathrm{a}, \mathrm{b})\end{array}$ \\
\hline
\end{tabular}

support, investigations may meet a dead end. Besides, it is well-known that, in comparison to other conditions, the pharmaceutical industry still lacks interest in the NTDs field.

Plants used in folk medicine to treat leishmaniasis could be a starting point for investigations aimed at finding new drugs with this action. A fact that collaborates with this study strategy is the restricted occurrence of iridoids in certain taxons. For keen eye and experienced researchers, the presence of these compounds in some genera is quite predictable. Thus, if the goal is to find iridoids with antileishmanial activity, the search based on ethnobotanical criteria would be corroborated by chemotaxonomy.

As discussed in this work, some iridoid types possess reactive moieties prone to undergo indiscriminate reactions in biological environments (e.g., tetracyclic iridoids molucidin 22 and plumericin 25). Hence, it is imperative the toxicological assessment of the iridoid class as a whole. Depending on the clinical manifestation, leishmaniasis requires long pharmacotherapy and even hospitalization; in this manner, adverse effects should be minimized at the maximum. Malnourished patients and those with preexisting conditions such as Leishmania-HIV co-infection are recurrent in the leishmaniasis scenario, being more susceptible to treatment adverse effects. Both mechanism of action and toxicological studies should take advantage of in silico tools to assist in-depth investigations; for instance, this approach could help the development of semisynthetic iridoids, improve their selectivity towards a target, find new potential targets, or rationally design iridoid-based compounds through molecular simplification. Vendruscolo et al. (2019) indicated through in silico studies the importance of some structural patterns in iridoids with antileishmanial potential. The occurrence of iridoids as glycosides is another feature that may play a key role in their pharmacokinetics. In fact, this feature is very convenient for the development of drug delivery systems such as liposomal and niosomal preparations containing iridoids - highlighting the versatility of this class from a pharmaceutical technology point of view (Medda et al. 1999).

With regard to the antileishmanial assessment per se, we strongly recommend the inclusion of both Leishmania forms in the investigation workflow. In this review, it has been demonstrated how important is to 


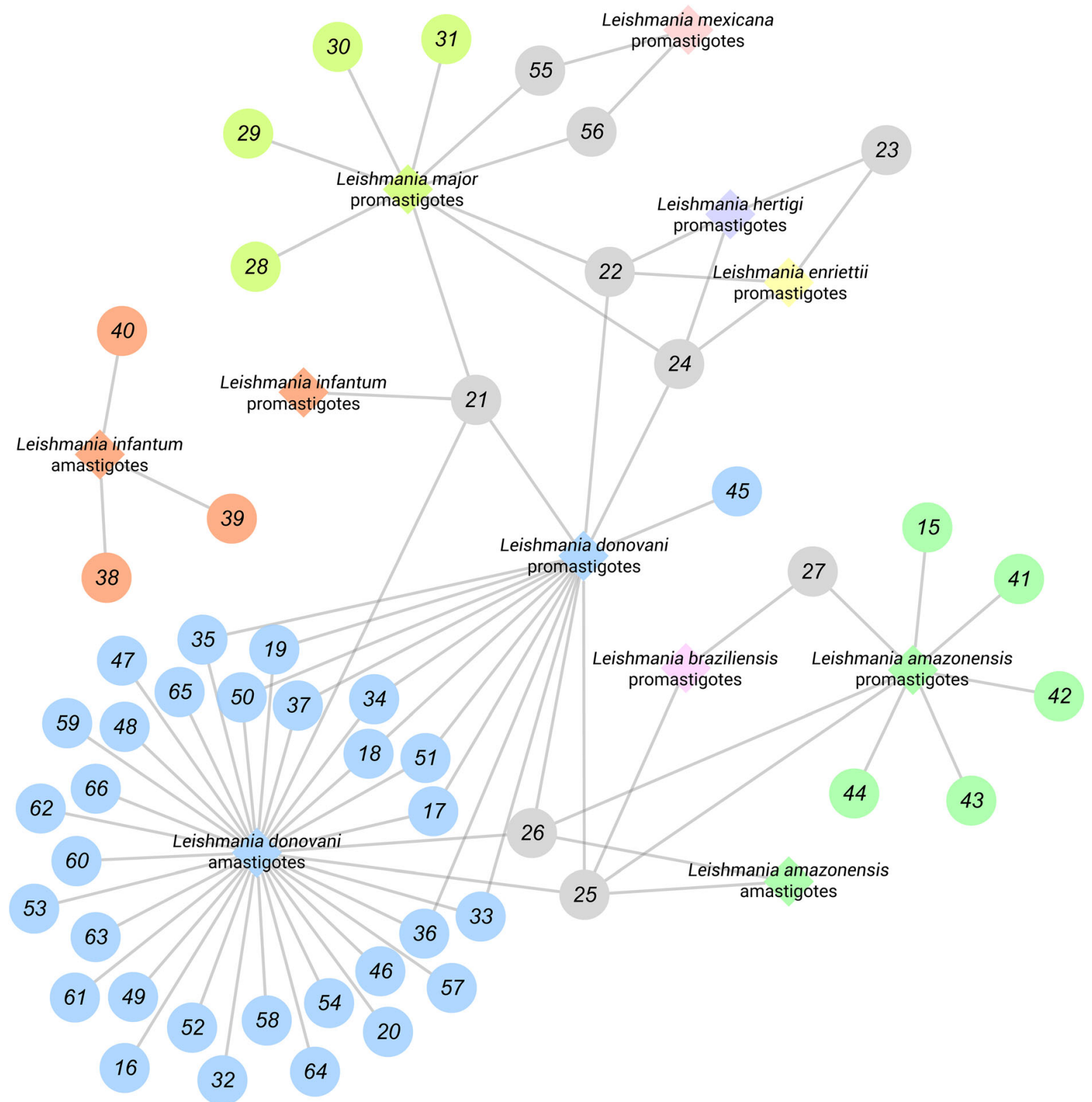

Fig. 15 General overview of iridoids evaluated against Leishmania spp. Each Leishmania species is represented as a rhombus and correlated according to the iridoids herein discussed. Iridoids assayed against more than one Leishmania

comprise all Leishmania forms in the search of novel antileishmanial compounds by evidencing that the activity may vary between promastigotes and amastigotes. Although promastigotes are opportune for screening purpose, the amastigote forms are of best interest, since clinical manifestations are related to these intracellular forms. Even more, we recommend the use of species $(\mathbf{2 1}, \mathbf{2 2}, \mathbf{2 3}, \mathbf{2 4}, \mathbf{2 5}, \mathbf{2 6}, \mathbf{2 7}, \mathbf{5 5}$, and $\mathbf{5 7})$ are represented as a gray circle. It is important to note that axenic and intracellular amastigotes were not differentiated in this representation

intracellular amastigotes rather than axenic amastigotes, considering the intracellular conditions simulate more accurately when the parasites establish in the host. We acknowledge that this workflow is a reflection of lack of funds, which is recurring in the NTDs area. To circumvent this issue, collaborations between research groups are essential and must be encouraged. 
Finally, the (Fig. 15) illustrates the current situation and dimension concerning which iridoids and Leishmania species have been most - and least - investigated so far. Surprisingly, antileishmanial assessment is concentrated on $L$. donovani amastigote forms, a species responsible for VL. However, this representation still corroborates the premise that promastigotes are normally assayed prior anti-amastigote evaluations, with some exceptions; for example, the isolates 38, 39, and 40 (Fig. 9) were exclusively assayed against $L$. infantum amastigotes. Even though these compounds did not exhibit activity, it does not exclude the possibility of leishmanicidal action towards other Leishmania species. Arguably the most important information of this representation is the scarcity of investigation of some species, bringing to the light an opportunity for research groups to explore. We intent to inspire researchers to use this representation as a guide for further studies. Moreover, we stimulate the assessment of iridoids against Leishmania species with few available data, as it occurs with L. amazonensis, L. mexicana, L. braziliensis, and L. infantum. The opportunity to innovate in the area is evident, and iridoids represent a potential antileishmanial class worth exploring.

Acknowledgements The authors wish to thank the Brazilian funding agency CAPES (Coordenação de Aperfeiçoamento de Pessoal de Nível Superior) for financial support. The authors also would like to thank the graphic designer Fernanda Gularte Keller for the remarkable hand-drawn life cycle illustration.

Funding No funding was received for conducting this study.

Code availability Not applicable.

Availability of data and material The data thapports the findings of this study were accessed through Universidade Federal do Rio Grande do Sul institution.

\section{Declaration}

Conflicts of interest The authors have no conflicts of interest to declare.

\section{References}

Abdel-Mageed WM, Backheet EY, Khalifa AA et al (2012) Antiparasitic antioxidant phenylpropanoids and iridoid glycosides from Tecoma mollis. Fitoterapia 83:500-507. https://doi.org/10.1016/j.fitote.2011.12.025
Agrawal J, Pal A (2013) Nyctanthes arbor-tristis Linn - A critical ethnopharmacological review. J Ethnopharmacol 146:645-658. https://doi.org/10.1016/j.jep.2013.01.024

Alkhaldi AA, Musa A, Mostafa EM et al (2020) Docking studies and antiprotozoal activity of secondary metabolites isolated from Scrophularia syriaca Benth. growing in Saudi Arabia. Rec Nat. Prod 14:23-30. https://doi.org/10.25135/ rnp.19.03.1224

Amin A, Tuenter E, Exarchou V et al (2016) Phytochemical and pharmacological investigations on Nymphoides indica leaf extracts. Phytother Res 30:1624-1633. https://doi.org/10. 1002/ptr.5663

Amoa-Bosompem M, Ohashi M, Mosore M-T et al (2016) In vitro anti-Leishmania activity of tetracyclic iridoids from Morinda lucida, Benth. Trop Med Health 44:25. https://doi.org/10.1186/s41182-016-0026-5

Atay I, Kirmizibekmez H, Kaiser M et al (2016) Evaluation of in vitro antiprotozoal activity of Ajuga laxmannii and its secondary metabolites. Pharm Biol 54:1808-1814. https:// doi.org/10.3109/13880209.2015.1129542

Azerigyik FA, Amoa-Bosompem M, Tetteh T et al (2018) In vitro mechanistic assays of tetracyclic iridoid compounds isolated from Morinda lucida Benth. in Leishmania species. Eur J Med Plants 25:1-14. https://doi.org/10.9734/ EJMP/2018/44972

Bailey F, Mondragon-Shem K, Haines LR et al (2019) Cutaneous leishmaniasis and co-morbid major depressive disorder: a systematic review with burden estimates. PLoS Negl Trop Dis 13(2):e0007092. https://doi.org/10.1371/ journal.pntd.0007092

Bello O, Ogbesejana A, Osibemhe M (2018) Iridoid glucosides from Vitex grandifolia displayed anti-inflammatory and antileishmania effects and structure activity relationship. J Appl Sci Environ Manage 22:373-378. https://doi.org/10. 4314/jasem.v22i3.14

Bennis I, De Brouwere V, Belrhiti Z et al (2018) Psychosocial burden of localized cutaneous leishmaniasis: a scoping review. BMC Public Health 18:358. https://doi.org/10. 1186/s12889-018-5260-9

Bhattamisra SK, Yap KH, Rao V et al (2019) Multiple biological effects of an iridoid glucoside, catalpol, and its underlying molecular mechanisms. Biomolecules 10:32. https://doi.org/10.3390/biom10010032

Bodimeade C, Marks M, Mabey D (2019) Neglected tropical diseases: elimination and eradication. Clin Med 19:157-160. https://doi.org/10.7861/clinmedicine.19-2157

Boniface PK, Ferreira EI (2019) Flavonoids as efficient scaffolds: recent trends for malaria, leishmaniasis, Chagas disease, and dengue. Phytother Res 33:2473-2517. https:// doi.org/10.1002/ptr.6383

Castillo D, Arevalo J, Herrera F et al (2007) Spirolactone iridoids might be responsible for the antileishmanial activity of a Peruvian traditional remedy made with Himatanthus sucuuba (Apocynaceae). J Ethnopharmacol 112:410-414. https://doi.org/10.1016/j.jep.2007.03.025

Chakravarty J, Sundar S (2019) Current and emerging medications for the treatment of leishmaniasis. Exp Opin Pharmacother 20:1251-1265. https://doi.org/10.1080/ 14656566.2019 .1609940 
Charlton RL, Rossi-Bergmann B, Denny PW et al (2018) Repurposing as a strategy for the discovery of new antileishmanials: the-state-of-the-art. Parasitology 145:219-236. S0031182017000993

https://doi.org/10.1017/

Conceição-Silva F, Morgado FN (2019) Leishmania spp-host interaction: there is always an onset, but is there an end? Front Cell Infect Microbiol 9:330. https://doi.org/10.3389/ fcimb.2019.00330

de Menezes JP, Saraiva EM, da Rocha-Azevedo B (2016) The site of the bite: Leishmania interaction with macrophages, neutrophils, and the extracellular matrix in the dermis. Parasit Vectors 9:264-264. https://doi.org/10.1186/ s13071-016-1540-3

de Sa Barreto LCL, de B Carvalho E, da Cunha-Filho MSS et al (2007) Atividade moluscicida de extratos e de aucubina de Vitex gardneriana schauer (Verbenaceae) em embriões da Biomphalaria glabrata. Latin Am J Pharm 26:339-345

Dorlo TP, Balasegaram M, Beijnen JH et al (2012) Miltefosine: a review of its pharmacology and therapeutic efficacy in the treatment of leishmaniasis. J Antimicrob Chemother 67:2576-2597. https://doi.org/10.1093/jac/dks275

Dostálová A, Volf P (2012) Leishmania development in sand flies: parasite-vector interactions overview. Parasit Vectors 5:276. https://doi.org/10.1186/1756-3305-5-276

Drewes SE, Kayonga L, Clark TE et al (1996) Iridoid molluscicidal compounds from Apodytes dimidiata. J Nat Prod 59:1169-1170. https://doi.org/10.1021/np960404y

Ehrenberg JP, Zhou X-N, Fontes G et al (2020) Strategies supporting the prevention and control of neglected tropical diseases during and beyond the COVID-19 pandemic. Infect Dis Poverty 9:86. https://doi.org/10.1186/s40249020-00701-7

Elamin MH, AL-Maliki SS, (2014) Leishmanicidal and apoptotic activities of oleuropein on Leishmania major. Int J Clin Pharmacol Ther 52:880-888. https://doi.org/10.5414/ cp202102

Emami S, Tavangar P, Keighobadi M (2017) An overview of azoles targeting sterol $14 \alpha$-demethylase for antileishmanial therapy. Eur J Med Chem 135:241-259. https://doi. org/10.1016/j.ejmech.2017.04.044

Filho VC, Meyre-Silva C, Niero R et al (2013) Evaluation of antileishmanial activity of selected Brazilian plants and identification of the active principles. Evid Based Complem Altern Med 2013:265025

Franzyk H (2000) Synthetic aspects of iridoid chemistry. In: Herz W, Falk H, Kirby GW, Moore RE (eds) Fortschritte der Chemie organischer Naturstoffe/progress in the chemistry of organic natural products. Springer, Vienna

Geiger A, Bossard G, Sereno D et al (2016) Escaping deleterious immune response in their hosts: lessons from trypanosomatids. Front Immunol 7:212. https://doi.org/10.3389/ fimmu.2016.00212

Ghosh S, Debnath S, Hazra S et al (2011) Valeriana wallichii root extracts and fractions with activity against Leishmania spp. Parasitol Res 108:861-871. https://doi.org/10.1007/ s00436-010-2127-0

Girish C, Pradhan SC (2008) Drug development for liver diseases: focus on picroliv, ellagic acid, and curcumin. Fundam Clin Pharmacol 22:623-632. https://doi.org/10.1111/ j.1472-8206.2008.00618.x
Glaser J, Schultheis M, Moll H et al (2015) Antileishmanial and cytotoxic compounds from Valeriana wallichii and identification of a novel nepetolactone derivative. Molecules 20:5740-5753.

https://doi.org/10.3390/ molecules 20045740

Gonçalves GA, Spillere AR, das Neves GM, et al (2020) Natural and synthetic coumarins as antileishmanial agents: a review. Eur J Med Chem 203:112514. https://doi.org/10. 1016/j.ejmech.2020.112514

Graebin CS, Uchoa FD, Bernardes LSC et al (2009) Antiprotozoal agents: an overview. AntiInfect Agents Med Chem 8:345-366. https://doi.org/10.2174/187152109789760199

Guo N, Jin C, Shen L et al (2019) Chemical components, pharmacological actions, and clinical applications of Rhizoma Picrorhizae. Phytother Res 34:1071-1082. https:// doi.org/10.1002/ptr.6591

Gupta S, Ramesh SC, Srivastava VM (2005) Efficacy of picroliv in combination with miltefosine, an orally effective antileishmanial drug against experimental visceral leishmaniasis. Acta Trop 94:41-47. https://doi.org/10.1016/j. actatropica.2004.11.009

Hamdi HK, Castellon R (2005) Oleuropein, a non-toxic olive iridoid, is an anti-tumor agent and cytoskeleton disruptor. Biochem Bioph Res Co 334:769-778. https://doi.org/10. 1016/j.bbrc.2005.06.161

Hassen I, Casabianca H, Hosni K (2015) Biological activities of the natural antioxidant oleuropein: exceeding the expectation - a mini-review. J Funct Foods 18:926-940. https:// doi.org/10.1016/j.jff.2014.09.001

Hussain H, Al-Harrasi A, Al-Rawahi A et al (2014) Fruitful decade for antileishmanial compounds from 2002 to late 2011. Chem Rev 114:10369-10428. https://doi.org/10. $1021 / \mathrm{cr} 400552 \mathrm{x}$

Hussain H, Green IR, Saleem M et al (2019) Therapeutic potential of Iridoid derivatives: patent review. Inventions 4:29. https://doi.org/10.3390/inventions4020029

Jensen SR (1992) Systematic implications of the distribution of iridoids and other chemical compounds in the loganiaceae and other families of the asteridae. Ann Missouri Bot Garden 79:284-302. https://doi.org/10.2307/2399770

Jensen SR, Schripsema J (2002) Chemotaxonomy and pharmacology of Gentianaceae. In: Struwe L, Albert V (eds) Gentianaceae - systematics and natural history, vol Chapter. 6. Cambridge University Press, Cambridge, pp 573-631

Kaye P, Scott P (2011) Leishmaniasis: complexity at the hostpathogen interface. Nat Rev Microbiol 9:604-615. https:// doi.org/10.1038/nrmicro2608

Khan ZK, Manglani A, Shukla PK et al (1995) Immunomodulatory effect of plant extracts and iridoid glucosides from Nyctanthes arbortristis against systemic candidiasis in mice. Int J Pharmacogn 33:297-304. https://doi.org/10. 3109/13880209509065382

Kirmizibekmez H, Atay I, Kaiser M et al (2011) Antiprotozoal activity of Melampyrum arvense and its metabolites. Phytother Res 25:142-146. https://doi.org/10.1002/ptr. 3233

Kirmizibekmez H, Calis I, Perozzo R et al (2004) Inhibiting activities of the secondary metabolites of Phlomis brunneogaleata against parasitic protozoa and plasmodial enoyl-ACP reductase, a crucial enzyme in fatty acid 
biosynthesis. Planta Med 70:711-717. https://doi.org/10. 1055/s-2004-827200

Kubo I, Matsumoto A (1984) Molluscicides from olive Olea europaea and their efficient isolation by counter-current chromatographies. J Agric Food Chem 32:687-688. https://doi.org/10.1021/jf00123a067

Kumar V, Mandal R, Das S et al (2020) Kala-azar elimination in a highly-endemic district of Bihar, India: a success story. PLoS Negl Trop Dis 14(5):e0008254. https://doi.org/10. 1371/journal.pntd.0008254

Kwofie KD, Tung NH, Suzuki-Ohashi M et al (2016) Antitrypanosomal activities and mechanisms of action of novel tetracyclic iridoids from Morinda lucida Benth. Antimicrob Agents Chemother 60:3283-3290. https://doi.org/10. 1128/AAC.01916-15

Kyriazis I, Smirlis D, Papadaki A et al (2017) Leishmanicidal activity of oleuropein: Leishmania donovani promastigote cell death through a possibly ROS-independent mechanism. J Pharmacogn Nat Prod 3:1000141. https://doi.org/ 10.4172/2472-0992.1000141

Kyriazis ID, Koutsoni OS, Aligiannis N et al (2016) The leishmanicidal activity of oleuropein is selectively regulated through inflammation- and oxidative stress-related genes. Parasit Vectors 9:441. https://doi.org/10.1186/ s13071-016-1701-4

Kyriazis JD, Aligiannis N, Polychronopoulos P et al (2013) Leishmanicidal activity assessment of olive tree extracts. Phytomedicine 20:275-281. https://doi.org/10.1016/j. phymed.2012.11.013

Malecela MN (2019) Reflections on the decade of the neglected tropical diseases. Int Health 11:338-340. https://doi.org/ 10.1093/inthealth/ihz048

Matos APS, Viçosa AL, Ré MI et al (2020) A review of current treatments strategies based on paromomycin for leishmaniasis. J Drug Deliv Sci Technol 57:101664. https://doi. org/10.1016/j.jddst.2020.101664

Medda S, Mukhopadhyay S, Basu MK (1999) Evaluation of the in-vivo activity and toxicity of amarogentin, an antileishmanial agent, in both liposomal and niosomal forms. J Antimicrob Chemother 44:791-794. https://doi.org/10. 1093/jac/44.6.791

Mittal N, Gupta N, Saksena S et al (1998) Protective effect of picroliv from Picrorhiza kurroa against Leishmania donovani infections in Mesocricetus auratus. Life Sci 63:1823-1834. https://doi.org/10.1016/s00243205(98)00456-1

Mohamed NM, Makboul MA, Farag SF et al (2017) Iridoid and phenylpropanoid glycosides from the roots of Lantana montevidensis. Med Chem Res 26:1117-1126. https://doi. org/10.1007/s00044-017-1817-x

Moradin N, Descoteaux A (2012) Leishmania promastigotes: building a safe niche within macrophages. Front Cell Infect Microbiol 2:121. https://doi.org/10.3389/fcimb.2012. 00121

Ortega V, Giorgio S, de Paula E (2017) Liposomal formulations in the pharmacological treatment of leishmaniasis: a review. J Liposome Res 27:234-248. https://doi.org/10. 1080/08982104.2017.1376682

Pal D, Sur S, Mandal S et al (2012) Prevention of liver carcinogenesis by amarogentin through modulation of $G_{1} / S$ cell cycle check point and induction of apoptosis.
Carcinogenesis 33:2424-2431. https://doi.org/10.1093/ carcin/bgs 276

Pasdaran A, Hamedi A (2017) The genus Scrophularia: a source of iridoids and terpenoids with a diverse biological activity. Pharm Biol 55:2211-2233. https://doi.org/10.1080/ 13880209.2017.1397178

Podinovskaia M, Descoteaux A (2015) Leishmania and the macrophage: a multifaceted interaction. Fut Microbiol 10:111-129. https://doi.org/10.2217/fmb.14.103

Puri A, Saxena RP, Sumati, et al (1992) Immunostimulant activity of picroliv, the iridoid glycoside fraction of $P i$ crorhiza kurroa, and its protective action against Leishmania donovani infection in hamsters. Planta Med 58:528-532. https://doi.org/10.1055/s-2006-961542

Raj S, Sasidharan S, Balaji SN et al (2020) Review on natural products as an alternative to contemporary anti-leishmanial therapeutics. J Proteins Proteom 11:135-158. https://doi. org/10.1007/s42485-020-00035-w

Rani A, Sharma A (2013) The genus Vitex: a review. Pharmacogn rev 7:188-198. https://doi.org/10.4103/0973-7847. 120522

Ray S, Majumder HK, Chakravarty AK et al (1996) Amarogentin, a naturally occurring secoiridoid glycoside and a newly recognized inhibitor of topoisomerase I from Leishmania donovani. J Nat Prod 59:27-29. https://doi.org/ 10.1021/np960018g

Rocha e Silva LF, Lima ES, Vasconcellos MCD et al (2013) In vitro and in vivo antimalarial activity and cytotoxicity of extracts, fractions, and a substance isolated from the Amazonian plant Tachia grandiflora (Gentianaceae). Mem Inst Oswaldo Cruz 108:501-507. https://doi.org/10.1590/ S0074-02762013000400017

Rocha LG, Almeida JR, Macêdo RO et al (2005) A review of natural products with antileishmanial activity. Phytomedicine 12:514-535. https://doi.org/10.1016/j.phymed. 2003.10.006

Roque ALR, Jansen AM (2014) Wild and synanthropic reservoirs of Leishmania species in the Americas. Int J Parasitol Parasit nd Wildl 3:251-262. https://doi.org/10.1016/j. ijppaw.2014.08.004

Rossi M, Fasel N (2017) How to master the host immune system? Leishmania parasites have the solutions! Int Immunol 30:103-111. https://doi.org/10.1093/intimm/dxx075

Sane SA, Shakya N, Gupta S (2011) Immunomodulatory effect of picroliv on the efficacy of paromomycin and miltefosine in combination in experimental visceral leishmaniasis. Exp Parasitol 127:376-381. https://doi.org/10.1016/j.exppara. 2010.09.003

Scotti MT, Scotti L, Ishiki H et al (2016) Natural products as a source for antileishmanial and antitrypanosomal agents. Comb Chem High Throughput Screen 19:537-553. https:// doi.org/10.2174/1386207319666160506123921

Séguin O, Descoteaux A (2016) Leishmania, the phagosome, and host responses: the journey of a parasite. Cell Immunol 309:1-6. https://doi.org/10.1016/j.cellimm.2016.08.004

Shakya N, Sane SA, Gupta S (2011a) Antileishmanial efficacy of fluconazole and miltefosine in combination with an immunomodulator - picroliv. Parasitol Res 108:793-800. https://doi.org/10.1007/s00436-010-2230-2

Shakya N, Sane SA, Vishwakarma P et al (2011b) Improved treatment of visceral leishmaniasis (kala-azar) by using 
combination of ketoconazole, miltefosine with an immunomodulator-picroliv. Acta Trop 119:188-193. https://doi.org/10.1016/j.actatropica.2011.05.017

Sharma U, Singh D, Kumar P et al (2011) Antiparasitic activity of plumericin isoplumericin isolated from Plumeria bicolor against Leishmania donovani. Indian $\mathrm{J}$ Med Res 134:709-716

Shukla AK, Patra S, Dubey VK (2011) Deciphering molecular mechanism underlying antileishmanial activity of $\mathrm{Nyc}$ tanthes arbortristis, an Indian medicinal plant. J Ethnopharmacol 134:996-998. https://doi.org/10.1016/j. jep.2011.01.044

Shukla AK, Patra S, Dubey VK (2012) Iridoid glucosides from Nyctanthes arbortristis result in increased reactive oxygen species and cellular redox homeostasis imbalance in Leishmania parasite. Eur J Med Chem 54:49-58. https:// doi.org/10.1016/j.ejmech.2012.04.034

Singha UK, Guru PY, Sen AB et al (1992) Antileishmanial activity of traditional plants against Leishmania donovani in golden hamsters. Int J Pharmacog 30:289-295. https:// doi.org/10.3109/13880209209054015

Sundar S, Chakravarty J, Meena LP (2019) Leishmaniasis: treatment, drug resistance and emerging therapies. Exp Opin Orphan Drugs 7:1-10. https://doi.org/10.1080/ 21678707.2019.1552853

Sundar S, Singh A (2016) Recent developments and future prospects in the treatment of visceral leishmaniasis. Ther Adv Infect Dis 3:98-109

Sunyoto T, Boelaert M, Meheus F (2019) Understanding the economic impact of leishmaniasis on households in endemic countries: a systematic review. Expert Rev Anti Infect Ther 17:57-69. https://doi.org/10.1080/14787210.2019. 1555471

Suzuki M, Tung NH, Kwofie KD et al (2015) New anti-trypanosomal active tetracyclic iridoid isolated from Morinda lucida Benth. Bioorg Med Chem Lett 25:3030-3033. https://doi.org/10.1016/j.bmcl.2015.05.003

Tamura S, Kubata BK, Syamsurizal, et al (2010) New antimalarial phenylpropanoid conjugated iridoids from Morinda morindoides. Bioorg Med Chem Lett 20:1520-1523. https://doi.org/10.1016/j.bmcl.2010.01.095

Tandon JS, Srivastava V, Guru PY (1991) Iridoids: a new class of leishmanicidal agents from Nyctanthes arbortristis. J Nat Prod 54:1102-1104. https://doi.org/10.1021/ np50076a030

Tasdemir D, Brun R, Franzblau SG et al (2008) Evaluation of antiprotozoal and antimycobacterial activities of the resin glycosides and the other metabolites of Scrophularia cryptophila. Phytomedicine 15:209-215. https://doi.org/ 10.1016/j.phymed.2007.07.032

Tasdemir D, Brun R, Perozzo R, Dönmez AA (2005a) Evaluation of antiprotozoal and plasmodial enoyl-ACP reductase inhibition potential of Turkish medicinal plants. Phytother Res 19:162-166. https://doi.org/10.1002/ptr.1648

Tasdemir D, Güner ND, Perozzo R et al (2005b) Anti-protozoal and plasmodial FabI enzyme inhibiting metabolites of Scrophularia lepidota roots. Phytochemistry 66:355-362. https://doi.org/10.1016/j.phytochem.2004.11.013

Tiwari N, Gedda MR, Tiwari VK et al (2018) Limitations of current therapeutic options, possible drug targets, and scope of natural products in the control of leishmaniasis. Mini Rev Med Chem 18:26-41. https://doi.org/10.2174/ 1389557517666170425105129

Torres-Guerrero E, Quintanilla-Cedillo M, Ruiz-Esmenjaud J et al (2017) Leishmaniasis: a review. Research 6:750

Tundis R, Loizzo MR, Menichini F et al (2008) Biological and pharmacological activities of iridoids: recent developments. Mini Rev Med Chem 8:399-420. https://doi.org/10. 2174/138955708783955926

Ullah N, Nadhman A, Siddiq S et al (2016) Plants as antileishmanial agents: current scenario. Phytother Res 30:1905-1925. https://doi.org/10.1002/ptr.5710

Vendruscolo MH, das Neves GM, Kagami LP, et al (2019) In vitro and in silico activity of iridoids against Leishmania amazonensis. Curr Drug Discov Technol 16:173-183. https://doi.org/10.2174/1570163814666171002102058

Verma PC, Basu V, Gupta V et al (2009) Pharmacology and chemistry of a potent hepatoprotective compound picroliv isolated from the roots and rhizomes of Picrorhiza kurroa royle ex Benth. (kutki). Curr Pharm Biotechnol 10:641-649. 138920109789069314 https://doi.org/10.2174/

Wang C, Gong X, Bo A et al (2020) Iridoids: research advances in their phytochemistry, biological activities, and pharmacokinetics. Molecules 25:287. https://doi.org/10.3390/ molecules 25020287

Zeng X, Guo F, Ouyang D (2020) A review of the pharmacology and toxicology of aucubin. Fitoterapia 140:104443. https:// doi.org/10.1016/j.fitote.2019.104443

Publisher's Note Springer Nature remains neutral with regard to jurisdictional claims in published maps and institutional affiliations. 